\title{
Allocation of Internal Cash Flow when Firms Pay Less Tax
}

\author{
David A. Guenther ${ }^{\mathrm{a}}$, Kenneth Njoroge ${ }^{\mathrm{b}}$, and Brian M. Williams ${ }^{\mathrm{c}}$ \\ aLundquist College of Business, University of Oregon, Eugene, OR 97403 USA \\ ${ }^{\mathrm{b}}$ Mason College of Business, College of William and Mary, Williamsburg, VA 23185 USA \\ 'Kelley School of Business, Indiana University, Bloomington, IN 47405 USA
}

August 2019

\begin{abstract}
We provide evidence about allocations of cash flow freed-up by not paying taxes ("tax-related cash"). Uncertainty about future repayments suggests firms may use tax-related cash more cautiously than other cash flow. We utilize a flow-of-funds model from finance to quantify the relative amounts of tax-related cash associated with various potential uses of operating cash flow. We find that firms allocate tax-related cash differently than other after-tax cash flow. Prior studies find tax avoiders hold more cash, and our results suggest this is because firms invest less (and save more) tax-related cash. We also find that the allocation of tax-related cash varies with relative financial constraints, economic uncertainty, and firms' multinational status in ways consistent with prior findings. For example, firms facing relatively higher levels of financial constraints invest a lower (higher) percentage of tax-related cash in capital expenditures (marketable securities and R\&D), possibly to preserve funds for future investment opportunities.

JEL classification: G31; H20

Key Words: Tax Avoidance; Cash Holdings; Financial Constraints; Multinational Corporations

Corresponding author:

Professor David A. Guenther

Lundquist College of Business

1208 University of Oregon

Eugene, OR 97403-1208

Phone: (541) 346-5384

Fax: (541) 346-3341

email: guenther@uoregon.edu

We acknowledge funding from the Finance and Securities Analysis Center at the Lundquist College of Business and the Frank Wood Accounting Research Fund at the Raymond A. Mason School of Business. We thank Lil Mills (editor) and two anonymous referees for helpful comments and suggestions. We also thank Johannes Voget (discussant), Denise Jones, Sonja Rego, Casey Schwab, Bridget Stomberg, Junwei Xia, the Indiana Tax Readings Group and workshop participants at Arizona State University, University of Colorado at Boulder, the Virginia Accounting Research Conference, and the European Institute for Advanced Study in Management Conference on Current Research in Taxation for helpful comments and suggestions. We thank Bill McDonald for making the data on linguistic-based financial constraints available on his website.
\end{abstract}




\section{Allocation of Internal Cash Flow when Firms Pay Less Tax}

\section{INTRODUCTION}

In defending its low effective tax rate to members of the U.S. Senate, Apple Inc. argued that the funds not paid in taxes were used for "expansion, acquisitions, and capital investment." Apple's assertion raises an interesting empirical question: what do U.S. public companies do with the additional cash flow associated with not paying taxes? Cash not paid in taxes, as measured by effective tax rates, has increased over time (Dyreng, Hanlon, Maydew, and Thornock 2017). To the extent managers engage in strategies that reduce firms' tax payments, pretax cash flow becomes available to be allocated to other uses, including new investment, cash savings, and debt repayment. In this study we investigate how firms allocate this additional cash flow, which we refer to as "tax-related cash."

Unlike other sources of cash flow, tax-related cash is subject to a unique risk in that corporations may need to repay the cash to the government and corporations have limited control over the timing and amount of potential repayment. The idea that tax-related cash may be subject to uncertainty due to potential repayment to the government is consistent with the argument in Dyreng, Hanlon and Maydew (2018 p. 1): "The tax authorities may challenge grey-area tax avoidance and ultimately prevail, resulting in the loss of the tax savings that initially came with the tax avoidance." In addition to the potential repayment of some portion of the tax savings, in extreme cases firms may have to pay back more than they avoided, due to interest and penalties.

\footnotetext{
${ }^{1}$ This quote is from the testimony to the Senate Permanent Subcommittee on Investigations on May 21, 2013.

${ }^{2}$ While our main interest is in cash flow related to lower tax payments, our regression approach identifies "taxrelated cash" as cash taxes paid that are unrelated to (i.e., orthogonal to) pretax cash flow. Our approach therefore applies equally to cases in which firms pay more tax. In other words, tax-related cash may be negative, indicating the alternative uses of cash that firms forgo in order to pay more tax.
} 
We expect that corporations will use tax-related cash differently than the cash flow obtained in other ways due to uncertainty about potential repayment of the tax-related cash to the government. We argue that managers attempt to minimize the negative impact of having to repay a portion of cash tax savings by either retaining a significant portion of tax-related cash or investing it in easily liquated assets. For example, if firms retain tax-related cash in a savings account, the impact of repayment may be minimal, particularly if the alternative was simply to pay the tax in the first place. On the other hand, if firms invest the tax-related cash in real assets, then repayment of the tax may require the firm to borrow, use up cash reserves, or liquidate the investment. For example, after Apple was ordered to pay $\$ 15$ billion in additional taxes by the European Union, Apple CEO Tim Cook noted that "the most profound and harmful effect of this ruling will be on investment and job creation." ${ }^{3}$ Due to this potential for repayment we predict that, relative to other after-tax cash flow, firms are more likely to allocate tax-related cash to uses that provide greater flexibility in the event they need to withdraw the cash for repayment.

Although tax-related cash is subject, on average, to more uncertainty than other pretax operating cash flow, ${ }^{4}$ empirical evidence of the extent to which firms attempt to reduce tax payments suggests that tax-related cash may be an important source of funds. This is especially true when firms face higher levels of financial constraints (Edwards, Schwab, and Shevlin 2016; Law and Mills 2015). For constrained firms, borrowing or other ways of obtaining cash are either unavailable or very costly. While firms facing higher levels of financial constraints may avoid taxes in order to fund especially promising current investment opportunities, these firms may also continue to face high levels of financial constraints in the future, and as such may use

\footnotetext{
${ }^{3}$ https://www.wsj.com/articles/apple-agrees-deal-with-ireland-over-15-billion-unpaid-tax-issue-1512392552

${ }^{4}$ Since tax-related cash is pretax cash flow that is not paid to the government, it is subject to the same business risks as other pretax cash flow. In addition, it is subject to a risk of repayment.
} 
the tax-related cash as extra liquidity to preserve future investment opportunities. Further, the cost of repayment for financially constrained firms will be higher because they have less financial resources available to repay the tax. Because of this higher cost of potential repayment, we predict that firms facing higher levels of financial constraints will use a smaller percentage of the tax-related cash for real investment than firms facing lower levels of financial constraints.

To test our predictions, we rely on an approach from the finance literature that allows us to estimate how firms use each dollar of cash flow (Chang, Dasgupta, Wong and Yao 2014). Because our research question addresses the allocation of cash that is not paid in tax, we split the total after-tax operating cash flow measure from Chang et al. (2014) into two portions. The first is related to paying less tax (tax-related cash). The second is other after-tax cash flow. We infer the allocation of both portions from separate regressions that utilize each use of cash as the dependent variable and cash taxes paid and pretax cash flow as the explanatory variables. We estimate these regressions on an unbalanced panel of profitable firms. The coefficient on cash taxes paid captures the use of tax-related cash, and the coefficient on pretax cash flow captures the use of other after-tax cash flow. We then conduct statistical tests of the differences in these coefficients. Holding pretax cash flow constant, as cash taxes paid decrease our system of regression equations allows us to estimate how much this decrease in tax payments affects other uses of cash, such as investment or debt repayment. ${ }^{5}$ In other words, as firms generate an additional dollar of tax-related cash, the uses of this cash (including saving) must also add up to one dollar. Thus, we are able to estimate how firms allocate (on average) each additional dollar

\footnotetext{
${ }^{5}$ Because we control for pretax cash flow in our regressions, the coefficient on cash taxes paid captures the allocation of tax-related cash, which is the portion of cash taxes paid that is orthogonal to pretax cash flow. Note, the portion of cash taxes paid that covaries with pretax cash flow will have the same regression coefficient as pretax cash flow, and therefore will be allocated to the same uses as pretax cash flow. We explain this in more detail in the Appendix B and in the Online Appendix.
} 
of tax-related cash. Our measure of tax-related cash represents cash the firm has not paid in taxes regardless of the reason. As such, it will pick up the effects of intentional tax avoidance strategies, as well as the effects of legislative tax subsidies and lower foreign tax rates. ${ }^{6}$

We further expand the model in Chang et al. (2014) to separately examine whether firms invest tax-related cash in "real investments" such as capital expenditures and acquisitions, or in marketable securities. ${ }^{7}$ This additional decomposition allows us to directly test our prediction that how firms invest tax-related cash depends on the liquidity of the investment. Given the importance of research and development in the economy, we also expand the model in Chang et al. (2014) by including R\&D as an additional use of cash for real investment. ${ }^{8}$

To address our research question we follow the design of Chang et al (2014) and estimate separate regressions in which we utilize the various components of investment as the dependent variables. Because of potential delay in the use of tax-related cash for investment, we measure our variables over a three year time period. ${ }^{9}$ Over this time period we find that corporations use tax-related cash more cautiously than other after-tax cash flow. Specifically a one-dollar increase in tax-related cash is associated with a 36 cent increase in real investment, while a one-dollar

\footnotetext{
${ }^{6}$ Because our cross-sectional regression controls for the covariance of cash taxes paid with pretax cash flow, this covariance can be thought of as an average tax "rate" across all sample firms. To the extent a firm's actual tax rate is lower than this average rate (for example, due to operations in a tax haven country) our measure of tax-related cash will reflect the lower tax payments.

${ }^{7}$ We classify capital expenditures and acquisitions, as well as R\&D spending, as "real investment" as these types of investment and spending are generally less liquid than investment in securities, and "one of the best known characteristics of real investment is that it is often irreversible" (Kogan 2004). Additionally, following Chang et al. (2014), we treat cash spent on inventory as a reduction in operating cash flow rather than as an investment.

${ }^{8}$ We acknowledge that R\&D spending is an accrual number and may not necessarily reflect cash spent on R\&D.

${ }^{9}$ The idea that tax-related cash would be subject to a delay in investment is consistent with anecdotal evidence from Puzder (2018), who argues that it could take businesses several years before they are able to properly invest the taxrelated cash under the new tax bill. "For example, in the business sector where I was a chief executive for more than 16 years, if restaurant owners decide to open new locations based on the increased profits they expect to receive from tax cuts, they would first have to find the right real estate. The owners would then need to negotiate a lease or a purchase, obtain the required zoning approvals and permits, hire contractors, build the restaurants and staff them. That can take up to two years - more in states such as California where zoning and permitting requirements are extensive and onerous."
} 
increase in other after-tax cash flow is associated with a 49 cent increase in real investment. In terms of the components of real investment we find that relative to a one-dollar increase in other after-tax cash flow, a one-dollar increase in tax-related cash is associated with a smaller increase in capital expenditures, a smaller increase in acquisitions, and about the same level of investment in R\&D. When compared to the allocation of other after-tax cash flow, firms in our sample also use a smaller percentage of tax-related cash for dividends, a higher percentage for securities investment, and a higher percentage for savings (i.e. an increase in the firm's cash balance). ${ }^{10}$

We next follow Law and Mills' (2015) use of a linguistic measure of financial constraints to examine how financial constraints influence the allocation of tax-related cash. ${ }^{11} \mathrm{We}$ find that when compared to other after-tax cash flow, the use of tax-related cash is more sensitive to financial constraints. Specifically for firms facing higher financial constraints a one-dollar increase in tax-related cash is associated with an 11 cent increase in real investment, while for firms facing lower financial constraints a one dollar increase in tax-related cash is associated with a 40 cent increase in real investment. In contrast, the allocations of after-tax cash flow to real investment are less affected by financial constraint (41 cents vs 51 cents). Thus, for firms facing higher levels of financial constraints the risk of repayment combined with the desire to use tax-related cash for additional liquidity may outweigh the benefit of using tax-related cash for current investment (i.e. the risk-reward tradeoff)..

Our next set of analyses examines the role of firm-level economic uncertainty in the allocation of tax-related cash. Given the usefulness of cash in allowing the firm flexibility to

\footnotetext{
${ }^{10}$ We find evidence consistent with Hanlon, Maydew and Saavadra (2017) in the sense that firms save a higher percentage and invest a lower percentage of tax-related cash compared with other after-tax cash flow.

${ }^{11}$ The linguistic measure addresses the concern of Farre-Mensa and Ljungqvist (2016) that "findings attributed to constraints may [...] reflect differences in the growth and financing policies of firms at different stages of their lifecycles."
} 
respond to challenges, we predict and find evidence in support of the idea that the negative consequences of potential tax repayment are more severe during times of economic uncertainty. We measure economic uncertainty using firm-level stock return volatility and find that for firms facing higher economic uncertainty a one-dollar increase in tax-related cash flow is associated with 19 cents of real investment while for firms facing lower economic uncertainty a one-dollar increase in tax-related cash is associated with 45 cents of real investment. In contrast, the allocation of after-tax cash flow to real investment is less affected by economic uncertainty (45 cents vs 56 cents). We also find that firms facing higher economic uncertainty use a larger proportion of their tax-related cash for debt reduction.

Finally, we examine how the allocation of tax-related cash differs for domestic and multinational firms. Academic researchers and the press have devoted substantial attention to the tax avoidance activities of multinational firms. In contrast, tax avoidance by domestic firms has received relatively little attention. We compare the use of tax-related cash for domestic and multinational firms and find that domestic firms use more of their tax-related cash for real investment than multinational firms. For multinational firms a one-dollar increase in tax-related cash flow is associated with 30 cents of real investment while a one-dollar increase in other aftertax cash flow is associated with 49 cents of real investment. In contrast for domestic firms the proportions of the two types of cash flow used for real investment are closer, as a one-dollar increase in tax-related cash is associated with 37 cent increase in real investment while a one dollar increase in other after-tax cash flow is associated with 50 cents of real investment.

Our study provides important evidence on how firms use tax-related cash, a question of interest to policymakers as well as academic researchers. Prior research has focused on one important source of tax-related cash - tax avoidance - and has often examined one use of tax- 
related cash at a time. This literature has found a positive association between tax avoidance and investment (Chen and Lai 2012; Mayberry 2012; Edwards, Schwab, and Shevlin 2016; Green and Kerr 2016; Goldman 2017), acquisitions (Hanlon, Lester, and Verdi 2015; Edwards, Kravet, and Wilson 2016), cash savings (Hanlon, Maydew, and Saavadra 2017), and shareholder payouts (Blouin and Krull 2009). However, these findings do not address the question of whether firms simply use the tax-related cash to do more of everything, and these studies do not compare the use of tax-related cash to that of other after-tax cash flow. An important contribution of our study is that our research design allows us to quantify the percentage of tax-related cash allocated to each use, and to compare this to the percentage of other after-tax cash flow allocated to the same purpose. Our evidence complements concurrent work by Jacob, Wentland, and Wentland (2018) who focus on uncertainty and temporary tax savings as well as work from Campbell (2018), who examines the use of permanent and temporary tax savings.

Another advantage of our use of the flow-of-funds model is that we are able to provide evidence on the allocation of tax-related cash and other after-tax cash flow even when statutory rates and tax incentives are unchanged. As such, our study is consistent with the call for research to provide broad sample evidence across multiple settings (Bloomfield, Nelson, Soltes 2016; Glaeser and Guay 2017). A better understanding of how firms allocate the cash flow freed-up by paying less tax, and how this allocation relates to financial constraints, economic uncertainty and multinational status, is of interest to both academics and policymakers, and helps stakeholders in understanding some investing and financing implications of lower tax payments.

Our study is subject to at least three limitations. First, because our measure of tax-related cash captures all sources of reduced tax payments rather than just those resulting from tax avoidance or tax aggressiveness, and because our sample contains a broad set of firms over 
approximately a twenty-five year period, our results may not map perfectly into other studies that examine specific types of firms, specific tax avoidance strategies, or responses to tax provisions at certain points in time. Second, our study focuses on profitable firms, and we are therefore only able to provide limited evidence on the use of tax-related cash by loss firms, which represent an important component of the economy. Third, although our estimate of the use of tax-related cash is unbiased, our estimate of the use of other after-tax cash flow is potentially biased in a way that would result in an understatement of the differences in the use of tax-related cash and other aftertax cash flow. Appendix B and the Online Appendix explain the source of this potential bias. Because this bias has the effect of understating the difference in our regression coefficients, our results should be viewed as a 'lower bound' on the differences in the allocations of tax-related cash and other after-tax cash flow.

\section{HYPOTHESES DEVELOPMENT}

We predict that firms will use tax-related cash will differently than other after-tax cash flow. Our hypotheses are based on three underlying ideas. First, our hypotheses focus on the relative uses of tax-related cash, which means we are comparing the use of tax-related cash with the use of other after-tax cash flow. For example, firms may use a portion of tax-related cash to increase real investment, and this may lead to a positive relation between levels of investment and measures of tax avoidance, as in Chen and Lai (2012), Mayberry (2012), Goldman (2017), and Edwards, Schwab, and Shevlin (2016). However, if we predict that the percentage of taxrelated cash used for real investment will be lower than the percentage of other after-tax cash flow used for real investment, our hypothesis would be that firms use less tax-related cash for real investment. This focus on the relative use of tax-related cash highlights an important 
difference between our research design and those of previous studies looking at a relation between tax avoidance and levels of investment.

The second idea underlying the development of our hypotheses is that if a firm uses relatively more tax-related cash for one purpose, it must by construction use relatively less taxrelated cash for one or more other purposes. Our research design is based on the cash flow identity, where any increase (decrease) in the use of cash flow for one purpose is offset by a corresponding decrease (increase) in the use of cash flow for one or more other purposes. For example, if we expect that firms save more of their tax-related cash than other after-tax cash flow (consistent with the findings in Hanlon et al. 2017), this suggests that firms use relatively less tax-related cash for at least one other purpose. ${ }^{12}$

The third idea underlying our hypotheses development is that tax-related cash is subject to more uncertainty than other after-tax cash flow because firms may have to repay tax-related cash to the taxing authorities in the future. Hanlon et al. (2017) view this uncertainty, to the extent it is reflected in the reserve for uncertain tax benefits, as a type of contingent liability. Not all tax-related cash is uncertain, and not all tax avoidance is uncertain; for example, there is little uncertainty in the use of accelerated depreciation. However, Dyreng et al. (2018) find a positive relation between increases in the FIN48 reserve (a proxy for uncertainty about tax repayment) and measures of tax avoidance, such as Cash ETRs. Thus, we assume that, on average, taxrelated cash is subject to more uncertainty (in terms of repayment risk) than other after-tax cash flow.

\footnotetext{
12 Note that this is a different prediction than saying that tax-avoiding firms have larger cash balances. To the extent tax avoiding firms generate more tax-related cash, they may use this additional cash for multiple purposes, and thus have higher cash balances, more investments, more debt repayments, etc. Our focus is on the percentage of taxrelated cash that is used for each purpose. A firm cannot use a higher percentage for all purposes.
} 


\section{Liquidity of Investment}

The cost of repayment of tax-related cash (plus possible interest and penalties) will depend in part on what the firm does with the cash. If the firm simply saves the tax-related cash, or invests it in securities, then repayment may make the firm no worse off than if the tax had been paid originally, especially if the firm settles a disputed tax claim for less than $100 \%$ repayment. However, if the tax-related cash has been invested in real assets, the firm may have to borrow, use up cash reserves, or liquidate the investment to repay the tax, which may be costly. Because other after-tax cash flow is not subject to a similar risk of repayment, our first hypothesis is:

H1a: Relative to other after-tax cash flow, tax-related cash is less likely to be used for real investments

H1b: Relative to other after-tax cash flow, tax-related cash is more likely to be saved

\section{Financial Constraints}

Tax planning can generate a substantial return (Mills, Erickson, and Maydew 1998) and research suggests that tax-related cash is an important source of operating cash flow, especially for firms subject to financial constraints (Campbell, Goldman, and Li 2018; Edwards, Schwab, and Shevlin 2016; Law and Mills 2015). This research provides evidence that when facing higher levels of financial constraints firms avoid more taxes. However, financially constrained firms face a relatively high cost if they use tax-related cash for real investments if they later have to repay the avoided tax, because these firms would find it more costly to borrow, given their financial constraints. This leads to our second hypothesis:

H2a: Tax-related cash is less likely to be used for real investments for firms facing high financial constraints 
H2b: Tax-related cash is more likely to be saved as cash or marketable securities for firms facing high financial constraints

\section{Economic Uncertainty}

Although we expect that real investment and savings are two major uses of tax-related cash, firms can also use tax-related cash to reduce their reliance on external financing. For example, the risk of debt covenant violations or other risks associated with debt (such as missing interest and/or principal payments) is expected to be higher during times of economic uncertainty. Thus, to the extent that the uncertainty of having to repay the avoided tax is less than the risk of violating debt covenants, during times of economic uncertainty managers may wish to use tax-related cash to reduce reliance on debt. Similarly, the cost of equity financing is also likely to be higher during times of economic uncertainty due to investors' risk aversion. To the extent that the cost of external financing (via debt or equity) is higher in times of economic uncertainty, using tax-related cash (rather than external financing) may be a preferred option.

Economic uncertainty also likely influences managers' decisions on how to "save" the tax-related cash. During times of economic uncertainty the value of cash is relatively stable compared with the value of marketable securities, and we therefore predict that managers prefer to use tax-related cash to increase cash holdings (rather than invest in marketable securities) when economic uncertainty is high.

This leads to our third hypothesis:

H3a: Tax-related cash is more likely to be used to reduce reliance on external financing in times of economic uncertainty

H3b: Tax-related cash is more likely to be saved as cash, rather than invested in marketable securities, in times of economic uncertainty 


\section{Multinational Status}

Because the U.S. only taxes domestic corporations on the foreign earnings of foreign subsidiaries when those earnings are repatriated to the domestic parent, there is a tax incentive to avoid this U.S. tax by keeping foreign earnings outside of the U.S. Prior research suggests his desire to avoid U.S. tax and the reported tax expense as an explanation for the large cash balances held by U.S. multinationals (Foley, Hartzell, Titman and Twite 2007; Blouin, Krull, and Robinson 2012). This suggests that multinationals will use more tax-related cash for savings.

However, Hanlon et al. (2017) find that domestic firms also hold large cash balances when subject to greater uncertainty. In addition, prior research suggests that multinational firms with tax-related foreign cash accumulations use the additional cash to make real investments (Hanlon, Lester and Verdi 2015; Edwards, Kravet and Wilson 2016). Because the prior evidence is consistent with multinational firms both saving more tax-related cash, and using tax-related cash for real investments although perhaps overpaying for them, we view the use of tax-related cash by multinationals as an empirical question, leading to our fourth hypothesis:

H4: Tax-related cash will be used differently by multinational and domestic firms

\section{RESEARCH DESIGN AND SAMPLE SELECTION}

Our research design allows us to estimate how firms in our sample use an additional dollar of cash flow, on average. Specifically, we modify the Chang et al. (2014) research design to start with pretax cash flow, rather than after-tax cash flow. We then include cash taxes paid as an additional use of cash. We estimate the use of tax-related cash based on the level of cash taxes paid, while controlling for the level of pretax cash flow. After controlling for pretax cash flow, the amount of cash taxes paid captures our measure of tax-related cash, with a lower level of 
cash taxes paid indicating more tax-related cash. We provide more detail on our research design below.

\section{"Flow of Funds" Model}

We start our flow of funds model by following Chang et al. (2014) ${ }^{13}$ in our use of the following cash flow identity from the cash flow statement:

$$
\text { Investment }_{t}+\Delta \text { Cash }_{t}+\text { Div }_{t}-\Delta D_{t}-\Delta E_{t}=C F_{t}
$$

The uses of funds include investment (Investment), dividends (Div), and the change in cash holdings ( $\triangle$ Cash). The sources of funds include internally generated operating cash flow $(C F)$ and external financing, defined as net debt issuance $(\Delta D)$ and net equity issuance $(\Delta E) .{ }^{14}$

To investigate how tax-related cash is used, we change (1) by adding cash taxes paid (TXPD) to $C F$ to generate cash flow before tax $C F B T$ (which we refer to as pretax cash flow), and add TXPD as an additional use of cash to the left side of (1). Equation (1) then becomes:

$$
\begin{gathered}
\text { Investment }_{t}+\Delta \text { Cash }_{t}+\text { Div }_{t}+T X P D_{t}-\Delta D_{t}-\Delta E_{t}=C F_{t}+T X P D_{t} \\
\text { Investment }_{t}+\Delta C a s h_{t}+\operatorname{Div}_{t}+T X P D_{t}-\Delta D_{t}-\Delta E_{t}=C F B T_{t}
\end{gathered}
$$

Because spending on $\mathrm{R} \& \mathrm{D}$ is another important potential use of cash that is similar to investment, we also add $R \& D$ expense to both sides of equation (2), so that our measure of pretax cash flow becomes cash flow before tax and $R \& D$ expense $(C F B T R D) .{ }^{15}$ This allows us to investigate how tax-related cash and other after-tax cash flow affect R\&D spending. ${ }^{16}$

\footnotetext{
${ }^{13}$ We provide a more complete explanation of the Chang et al. (2014) approach in the Online Appendix.

${ }^{14}$ Negative values for $\Delta D$ and $\Delta E$ represent net reductions in external financing (e.g., debt repayment, stock repurchases), which are uses of funds. Because these terms are subtracted, the net effect is subtracting a negative value, which increases the left side of (1).

${ }^{15}$ For brevity we will continue to refer to cash flow before tax and R\&D as "pretax cash flow."

${ }^{16}$ To the extent R\&D expense reflects accruals our measure of spending on R\&D will be noisy.
} 


$$
\begin{gathered}
\text { Investment }_{t}+\Delta \text { Cash }_{t}+\text { Div }_{t}+T X P D_{t}+R \& D_{t}-\Delta D_{t}-\Delta E_{t}=C F B T_{t}+R \& D_{t} \\
\text { Investment }_{t}+\Delta \text { Cash }_{t}+\text { Div }_{t}+T X P D_{t}+R \& D_{t}-\Delta D_{t}-\Delta E_{t}=C F B T R D_{t}
\end{gathered}
$$

We rearrange our equation to get cash taxes paid on the right side as follows:

$$
\text { Investment }_{t}+\Delta \text { Cash }_{t}+\operatorname{Div}_{t}+R \& D_{t}-\Delta D_{t}-\Delta E_{t}=C F B T R D_{t}-T X P D_{t}
$$

We regress each of the different uses of cash from the left side of equation (4) on pretax cash flow before R\&D (CFBTRD), cash taxes paid (TXPD), and a set of control variables $(X),{ }^{17}$ resulting in the following system of six equations:

$$
\begin{aligned}
& \text { Investment }_{i, t}=a^{I n v}+\beta^{I n v} C F B T R D_{i, t}+\gamma^{\text {Inv }}\left(-1 * T X P D_{i, t}\right)+\delta^{I n v} X_{i, t}+\varepsilon i, t^{I n v}
\end{aligned}
$$

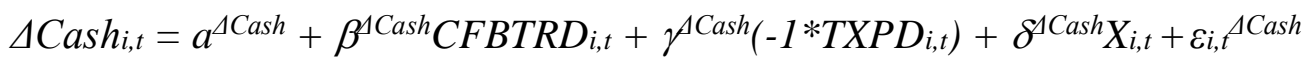

$$
\begin{aligned}
& \operatorname{Div}_{i, t}=a^{D i v}+\beta^{D i v} C F B T R D_{i, t}+\gamma^{D i v}\left(-1 * T X P D_{i, t}\right)+\delta^{D i v} X_{i, t}+\varepsilon i, t{ }^{D i v} \\
& R \& D_{i, t}=a^{R D}+\beta^{R D} C F B T R D_{i, t}+\gamma^{R D}\left(-1 * T X P D_{i, t}\right)+\delta^{R D} X_{i, t}+\varepsilon_{i, t}^{R D} \\
& \Delta D_{i, t}=a^{\Delta D}+\beta^{\Delta D} C F B T R D_{i, t}+\gamma^{\Delta D}\left(-1^{*} T X P D_{i, t}\right)+\delta^{\Delta D} X_{i, t}+\varepsilon i, t{ }^{\Delta D} \\
& \Delta E_{i, t}=a^{\Delta E}+\beta^{\Delta E} C F B T R D_{i, t}+\gamma^{\Delta E}\left(-1^{*} T X P D_{i, t}\right)+\delta^{\Delta E} X_{i, t}+\varepsilon_{i, t} \Delta E
\end{aligned}
$$

All variables are scaled by lagged total assets, and all regressions include year and firm fixed effects. To estimate the allocation of tax-related cash, we rely on the idea that, holding constant the level of pretax cash flow (CFBTRD), firms that pay less actual dollars of cash taxes (TXPD) have more cash flow for other uses. ${ }^{18}$

There is a subtle but important econometric point that we emphasize here about equations (5) - (10). The coefficient $\beta$ shows on average how firms allocate their pretax operating cash

\footnotetext{
${ }^{17}$ We show the control variables with a " $t$ " time subscript, although many of them are lagged values. In other words, the year $t$ control variable for a firm may be the value of the variable in year $t-1$.

${ }^{18}$ Note that to the extent cash taxes paid covaries with pretax cash flow its effect will be captured in the regression by pretax cash flow. We view any decrease (or increase) in cash taxes paid that is unrelated to (i.e., orthogonal to) pretax cash flow as tax-related cash, regardless of whether the decrease relates to tax avoidance.
} 
flow. However, because OLS regression coefficients reflect covariances, the $\beta$ coefficients will also capture after-tax cash flow to the extent cash taxes paid covary with pretax cash flow. The $\gamma$ coefficients show how our sample firms on average allocate tax-related cash, which is the amount of cash taxes paid that is orthogonal to pretax cash flow. For example, if Firm B has twice as much pretax cash flow as Firm A, the fact that Firm A's cash taxes paid are only half those of Firm B will not be considered as creating tax-related cash. Cash taxes paid that covary with the level of pretax cash flow end up with the same coefficient as pretax cash flow in our regression. We explain this in more detail in the Online Appendix.

To address the possibility of reverse causality regarding investment and spending on $R \& D$, we include lagged investment and lagged $R \& D$ as controls in all regressions. ${ }^{19}$ Because tax avoidance is typically measured by comparing cash taxes paid with pretax income (rather than cash flow), our regressions also add a control variable for total accruals, which when combined with pretax cash flow, represents a control for pretax income, measured at time $t$. We also include a control variable for special items following Dyreng et al (2017). To address the utilization of prior losses by firms that are profitable in the current year we also control for the lagged value of Tax Loss Carryforwards. In addition, we include the lagged values of the following: Market-to-Book, Natural Log of the Market Value of Equity, Natural Log of Total Assets, Tangibility, Sales Growth, Leverage, Pretax Profitability, and Retained Earnings. Finally, we measure cash flow over a three year period to allow for the possibility that investment occurs with a delay. ${ }^{20}$ Appendix A defines our variables.

\footnotetext{
${ }^{19}$ We acknowledge that spending on R\&D may generate a tax credit, thus creating more tax-related cash.

${ }^{20}$ For example, if a firm had operating cash flow in years 1,2 , and 3 of $\$ 40, \$ 25$, and $\$ 30$ respectively, our three year measure has operating cash flow of $\$ 40+\$ 25+\$ 30=\$ 95$. If the cash flow identity holds each year, the identity
} 
According to Chang et al. (2014), if the variables in equation (3) are properly defined so that the cash flow identity holds, then the following constraints should hold automatically, and no constraints will need to be explicitly imposed in the analysis.

$$
\begin{aligned}
& \beta^{I n v}+\beta^{\Delta C a s h}+\beta^{D i v}+\beta^{R D}-\beta^{\Delta D}-\beta^{\Delta E}=1 \\
& \gamma^{\text {Inv }}+\gamma^{4 \text { Cash }}+\gamma^{D i v}+\gamma^{R D}-\gamma^{\Delta D}-\gamma^{\Delta E}=1 \\
& \delta^{\text {Inv }}+\delta^{4 C a s h}+\delta^{D i v}+\delta^{R D}-\delta^{\Delta D}-\delta^{4 E}=0
\end{aligned}
$$

The estimated uses of cash should add up to one (or 100\%), on the basis of which we can infer how each dollar of additional cash flow is allocated. We estimate our system of equations using OLS without explicitly imposing constraints (11) - (13), although our results demonstrate these constraints hold throughout our analysis. ${ }^{21}$

We further extend Chang et al.'s design by decomposing Investment into its components: capital expenditures (CapEx), acquisitions (Acquisitions) and securities investments (Securities). We then separately estimate regressions for each of these components to provide evidence on how firms are allocating their cash flow. As it is a pure decomposition, the coefficients in these regressions will add up to the coefficients on the total investment allocation (Investment). We believe these results are informative because they provide finer evidence on how firms allocate their cash. For example, the allocation of cash to securities investment leads to different inferences than the allocation of cash to capital expenditures. In fact, as demonstrated in our analysis we find that firms in our sample allocate tax-related cash and other after-tax cash flow to

also holds in the three year period, similar to adding up four quarters of accounting data to construct an annual financial statement. The Online Appendix illustrates this and confirms that our identity continues to hold over a three year period. We also document that the identities hold in our empirical estimation in our discussion of Table 2. ${ }^{21}$ As noted in Chang et al. (2014): "Greene (2012) suggests that [seemingly unrelated regression] SUR estimates are equivalent to equation-by-equation OLS estimates if the same set of explanatory variables is included in each equation." This is the situation in our equations (5) - (10). 
the components of Investment quite differently, as they allocate more of their tax-related cash to securities investment, and less to capital expenditures and acquisitions, when compared to other after-tax cash flow.

\section{Sample Selection}

Our sample begins with all observations on the Compustat Annual Database from 1988 to 2017 with data necessary to compute our regression variables. We choose 1988 because this is the year that cash taxes paid becomes widely available on Compustat. We require firms to have non-missing data for assets, cash and equivalents, pretax income, cash taxes paid, and cash flow from operating activities. Following Chang et al. (2014), we impose the following sample selection criteria. First, we exclude financial institutions (SIC codes 6000 - 6999), public utilities (sic codes 4900 - 5000), and public administration and services (sic codes greater than 8000). Second, we require all sample firms to have total assets greater than one million dollars. Third, we exclude firms for which the market value of equity or sales revenue is less than one million dollars, the stock-price at the end of the fiscal year is less than 10 cents per share, the market-tobook ratio is less than 0.5 , or the absolute growth in assets is greater than $100 \% .^{22}$

Unlike Chang et al (2014), we omit loss firms for our primary analysis because our research design depends on identifying tax-related cash, which is the pretax cash flow that is not paid in taxes. A loss firm with negative taxable income (and negative pretax cash flow) may owe no income taxes in the current period, but this lack of tax paid is simply because the firm is not profitable, and cash not paid in tax due to a lack of profitability may be used differently from cash not paid in tax for reasons unrelated to the firm having losses. Accordingly, we exclude

\footnotetext{
${ }^{22}$ As in Chang et al. (2014), we exclude very small firms because they have very limited access to capital markets. We exclude firms with very high asset growth because they are often involved in major events such as mergers and acquisitions that result in unusual cash flow allocations.
} 
firms for which the sum of pretax income minus special items (PI - SPI) over the three year period is not positive. To the extent that profitable firms are more likely than loss firms to use funds for investment, and less likely to save them or use them to reduce reliance on debt or equity, our analysis will reflect these differences in allocations. As such, our study should only be viewed as providing evidence on the allocations of pretax cash flow and tax-related cash for firms that are profitable. Our main analysis can thus not speak to these allocations for loss firms. However due to the importance of loss firms to the economy, we estimate results for these firms separately and tabulate them in Section IV of our manuscript. Our final sample of profitable firm-year observations consists of 53,557 observations from 7,188 unique firms.

\section{Descriptive Statistics}

Table 1 presents the descriptive statistics for our sample. Panels A, and B present the cash flow variables measured over one or three years respectively. As expected, the means for each of the variables increase as they are aggregated over time. For example one-year pretax cash flow, $C F B T R D$, represents about 16.7 percent of assets in year $t$ - 1 , while pretax cash flow summed over three years (CFBTRD3) represents about 56.2 percent of assets in year $t$-1. Panel C describes our control variables for the sample on which we estimate uses of cash flow for three years, as we use this sample for the majority of our analysis.

\section{RESULTS}

\section{Allocation of Cash Flow}

Table 2 presents the results of our estimation of the allocation of other after-tax cash flow and tax-related cash for our full sample. These results provide evidence of our tests of Hypothesis 1, that relative to other after-tax cash flow, tax-related cash is more likely to be saved and less likely to be used for real investment. We use the coefficient on cash taxes paid to infer 
how firms allocate tax-related cash, which is the cash taxes paid that do not covary with pretax cash flow.

We first show that our decomposition of investment into its components holds. For example, in the total investment (Investment) equation, the coefficient estimate on tax-related cash (TXPD, column (1)) is 0.52 . When using each of the components of Investment separately as the dependent variable (columns (2)-(4)), the coefficient estimates on TXPD also sum to 0.52 (CapEx 0.20, Acquisitions 0.08, and Securities 0.24). The separation into components of Investment similarly holds for other after-tax cash flow $(C F B T R D)$ : Investment $(0.62)=$ CapEx $(0.27)+$ Acquisitions $(0.15)+$ Securities Investment (0.20). Finally, our full identities hold for all of the uses of cash, with the uses of cash adding up to one for both CFBTRD and TXPD. ${ }^{23}$ However, in some of the other tables the uses may not equal exactly one due to a rounding of the coefficients.

We next turn to our research question - the examination of how firms allocate tax-related cash. We find that nearly half of the use of tax-related cash for investment is in the form of securities, a type of investment with a high degree of liquidity that is often viewed differently from other less reversible investments such as capital expenditures and acquisitions. Specifically, the coefficient estimate on TXPD is 0.52 in the Investment equation and 0.24 in the Securities equation. Separation of investment into its components represents an important part of our

\footnotetext{
${ }^{23}$ For TXPD $(0.20 C p x+0.08 A c q+0.24 S i v+0.08 R \& D+0.34 \Delta C a s h+0.01 D i v--0.03 \Delta D--0.02 \Delta E)=1.00$. For CFBTRD: $0.27 C p x+0.15 A c q+0.20$ Siv $+0.07 R \& D+0.28 \Delta$ Cash +0.03 Div $--0.02 \Delta D-0.02 \triangle E=1.00$.
} 
research design, and distinguishes our results from those of Chang et al. (2014), as does our examination of $R \& D$ as a type of spending on investment. ${ }^{24}$

We also find that firms invest tax-related cash more cautiously than other after-tax cash flow. Over a three year period, a one-dollar increase in tax-related cash (TXPD) is associated with 36 cents of real investment, with 20 cents for CapEx, 8 cents for Acquisitions, and 8 cents for $R \& D$. In contrast, a one-dollar increase in other after-tax cash flow (CFBTRD) is associated with 49 cents of real investment, with 27 cents for CapEx, 15 cents for Acquisitions, and 7 cents for $R \& D$. Over the same three year period, we also find that firms save more of the tax-related cash flow than other after-tax cash flow as an increase in the firm's cash balance ( 34 cents vs. 28 cents).

The bottom row of Table 2 presents p-values for tests of each of our examined allocations. Compared to the allocations of other after-tax cash flow, our sample firms allocate a significantly lower percentage of tax-related cash to capital expenditures (CapEx), acquisitions (Acquisitions), and dividends (Div), and significantly higher percentage of tax-related cash to securities investment (Securities), and to increase the cash balance ( $\triangle$ Cash). These allocations are all significantly different at the 5\% level. Overall, we interpret the results in Table 2 as supporting $\mathrm{H} 1$ in that tax-related cash is less likely to be used for real investment, and more likely to be saved than other after-tax cash flow.

\footnotetext{
${ }^{24}$ We re-estimate our main analysis without including R\&D so that all of the sources and uses of cash come from the cash flow statement. We find the results are quite similar, with the exception that when not including R\&D the coefficients on $T X P D$ vs. $C F B T$ (cash flow before tax) for the use of cash to reduce reliance on equity financing (-0.04 and 0.00) are significantly different (p-value 0.08), whereas when including R\&D (as tabulated) we do not find the coefficients $(-0.02$ and 0.02$)$ to be significantly different ( $\mathrm{p}$ value 0.17 ).
} 


\section{Financially Constrained Firms}

We next partition firms based on relative level of financial constraints. Table 3 presents the results based on this partition. These results provide evidence of our tests of Hypothesis 2, that firms facing higher levels of financial constraints use less of their cash for real investment and instead use it to increase savings.

We measure financial constraints using the linguistic measure developed by Bodnaruk, Loughran and McDonald (2015). ${ }^{25}$ Our sample size decreases substantially in these tests due to data availability of the Bodnaruk et al (2015) linguistic financial constraint measure. The sample period for these tests starts in 1993, the first year this data is available. We compare firms in the highest tercile of financial constraints (relatively more constrained) with those in the lowest tercile of financial constraints, omitting observations in the middle tercile. To allow for tests of the differences between higher and lower constraints, we include the indicator variable for higher financial constraints in the regression, and interact this variable with all other regression variables (fully interacted model). This is equivalent to running two separate regressions, but with the advantage that it allows for simple tests of the differences on the coefficients for firms facing higher vs. lower financial constraints. The variable TXPD_HC (TXPD_LC) equals TXPD for firms facing higher (lower) financial constraints and zero otherwise, while the variable CFBTRD_HC (CFBTRD_LC) equals CFBTRD for firms facing higher (lower) financial constraints and zero otherwise.

\footnotetext{
25 The linguistic measure of financial constraints has two main advantages over other measures. First, the linguistic measure of financial constraints is less likely to be related to corporate lifecycle, which could itself be correlated with cash flow use. Second, the linguistic measure of financial constraints is useful in identifying both current and future constraints, and expected future constraints should influence the firm's current cash flow allocations.
} 
Overall, we find that find that financially constrained firms spend less of their tax-related cash on real investment, and instead use more of it for savings. For example, we find that a onedollar increase in tax-related cash for firms facing higher levels of financial constraints is associated with an 11 cent increase capital expenditures, acquisitions and R\&D. In contrast a one-dollar increase in tax-related cash for firms facing lower levels of financial constraint is associated with a 40 cent increase in capital expenditures, acquisitions, and R\&D. This result illustrates the importance of the breakdown of Investment into its components, as essentially all of the investment of tax-related cash for firms facing higher levels of financial constraints is in marketable securities. Specifically, the coefficient estimate on TXPD_HC is essentially the same in the Investment equation (0.49) as in the Securities equation (0.50). In contrast, for firms facing lower levels of financial constraints, capital expenditures (32 cents) represents nearly half of the amount spent on Investment (62 cents). Further, firms facing lower financial constraints spend about 26 cents of each dollar of tax-related cash on marketable securities, about half of the size of the coefficient for firms facing higher levels of financial constraints.

The use of other after-tax cash flow is somewhat less sensitive to financial constraints. A one-dollar increase in other after-tax cash flow for firms facing higher levels of financial constraint is associated with 21 cents of capital expenditures and 10 cents of acquisitions (CFBTRD_HC). For firms facing lower levels of constraints these amounts are 29 cents for capital expenditures and 17 cents for acquisitions (CFBTRD_LC). When compared to firms facing lower levels of financial constraints, firms facing higher levels of financial constraints use more of both types of cash for R\&D (12 cents vs 4 cents for tax-related cash, 10 cents vs 5 cents for other after-tax cash flow). 
The bottom of Table 3 shows statistical tests of the differences in coefficients. Relative to firms facing lower levels of financial constraints, firms facing higher levels of financial use significantly less of their tax-related cash for capital expenditures, and significantly more of their tax-related cash for securities investment and R\&D spending.

When compared to the use of other after-tax cash flow, firms facing higher financial constraints use less of their tax related cash for capital expenditures, acquisitions, and dividends, and more of their tax-related cash for investment in marketable securities and to increase the firm's cash balance. We do not find a significant difference in the allocation of tax-related cash and other after-tax cash flow to Investment. However, we find that each of the individual components of total investment is allocated differently, suggesting that the higher allocation of tax-related cash to securities investment offsets the lower allocation to capital expenditures and acquisitions. Relative to their use of other after-tax cash flow firms facing lower levels of financial constraint use less of their tax-related cash for acquisitions and dividends, and more of their tax related cash for marketable securities and to increase the firm's cash balance.

In sum, we find results consistent with prior studies in the sense that financially constrained firms use some of their tax-related cash for real investment (specifically $R \& D$ spending) ${ }^{26}$ However, we also find firms facing higher financial constraints use a smaller proportion of their tax-related cash for real investment than firms facing lower financial

\footnotetext{
${ }^{26}$ Chen and Lai (2012) examine a subsample of financially constrained firms (using KZ index and payout policy as measures of constraints) and find a positive and significant relation between tax avoidance and real investment. However, they fail to find a significant relation for a subsample of financially constrained firms when using the WW index. Although it is not their research question, in Table A6 of their Online Appendix Edwards et al (2016) document a negative relation between firm-level investment and Cash ETR for a subsample of financially constrained firms, when using the Z-score to define financial constraints. However, they fail to find a significant relation when using the $\mathrm{KZ}$ index to define financial constraints.
} 
constraints. We also find that regardless of the level of financial constraints, firms use less of their tax-related cash (compared to other after-tax cash flow) for real investment.

Overall, we interpret the results in Table 3 as supporting H2, that firms facing higher levels of financial constraints save more of their tax-related cash and use less of their tax-related cash for real investment. We find these differences when comparing the use of tax-related cash for firms facing higher and lower levels of financial constraints, and we also find that the allocation of tax-related cash is somewhat more sensitive to financial constraints than the allocation of other after-tax cash flow. This result is consistent with the argument in Law and Mills (2015) that financially constrained firms save cash not paid in taxes to preserve future investment opportunities, and is somewhat less consistent with the idea that financially constrained firms use cash not paid in taxes to fund current investment. One notable exception to this result is the use of tax-related cash by firms facing higher levels of financial constraints to fund $R \& D$, a possible avenue for future research.

\section{The Role of Economic Uncertainty in Cash Flow Allocation}

This section examines the effect of economic uncertainty on the allocation of tax-related cash. We measure economic uncertainty using stock return volatility, and compare firms in the highest tercile of stock return volatility to firms in the lowest tercile of stock return volatility, omitting observations in the middle tercile. The variable $T X P D \_H V\left(T X P D \_L V\right)$ equals $T X P D$ in times of higher (lower) firm-specific economic uncertainty and zero otherwise. The variables CFBTRD_HV $\left(C F B T R D \_L V\right)$ equal CFBTRD in times of higher (lower) firm-specific economic uncertainty and zero otherwise.

Table 4 presents our results. These results provide evidence of our tests of Hypothesis 3 , that firms facing higher levels of economic uncertainty use more of their tax-related cash to 
reduce reliance on economic uncertainty, and are more likely to save their cash as an increase in the cash balance rather than as marketable securities.

We find results consistent with Hypothesis 3 as firms use more of their tax-related cash to reduce reliance on external financing and as cash savings (rather than marketable securities) in times of higher economic uncertainty. Specifically in times of higher economic uncertainty a one-dollar increase in tax-related cash is associated with a 15 cent reduction in debt financing, a 43 cent increase in cash savings, and a 23 cent increase in securities investment (as noted in the coefficient estimates on $\left.T X P D \_H V\right)$. In contrast in times of lower uncertainty a one-dollar increase in tax-related cash is associated with a 10 cent increase in debt (more borrowing), a 18 cent increase in cash savings, and a 43 cent increase in securities (as noted in the coefficient estimates on $\left.T X P D \_L V\right){ }^{27}$

\section{Cash Flow Allocation for Domestic vs. Multinational Firms.}

This section presents the results when we partition our sample firms into domestic and multinational firms. We define a firm as multinational if they have foreign pretax income (or loss). The variable $T X P D \_D O M\left(T X P D \_M N C\right)$ equals $T X P D$ for domestic (multinational) firms and zero otherwise. The variable $C F B T R D \_D O M\left(C F B T R D \_M N C\right)$ equals $C F B T R D$ for domestic (multinational) firms and zero otherwise. These results provide evidence of our tests of Hypothesis 4, that multinational and domestic firms use tax-related cash differently.

We find that relative to domestic firms, multinational firms use more of their tax-related cash for securities investment and to increase the cash balance and less of their tax-related cash

\footnotetext{
${ }^{27} \mathrm{We}$ also find marginal evidence that during times of higher uncertainty, a lower percentage of tax-related cash is allocated to capital expenditures (0.06 vs. 0.18 ; p-value 0.10$)$, and acquisitions ( 0.05 vs. 0.18 ; p-value 0.12$)$. The amount of tax-related cash allocated to capital expenditures and acquisitions in times of higher economic uncertainty (0.06 and 0.05) is not significantly different from zero. In contrast we find that regardless of economic uncertainty, a statistically significant percentage of other after-tax cash flow is allocated to capital expenditures and acquisitions, respectively (higher uncertainty 0.23 and 0.12 ; lower uncertainty 0.22 and 0.28 ).
} 
to reduce reliance on equity financing. Specifically for multinational firms one dollar of taxrelated cash is associated with 39 cents of marketable securities, 41 cents of increased cash balance and 9 cents of increased equity financing (i.e. stock issuance). In contrast, for domestic firms a one-dollar increase in tax-related cash is associated with 17 cents of marketable securities, 31 cents of increased cash balance, and 6 cents of reduced reliance on equity financing (i.e. stock repurchases).

When compared to their use of other after-tax cash flow, multinational firms use more of their tax-related cash for securities investment (39 cents vs. 24 cents) and to increase the firm's cash balance (41 cents vs 29 cents). Multinational firms also use less tax-related cash (compared to other after-tax cash flow) for acquisitions ( 7 cents and 18 cents $)^{28}, \mathrm{R} \& \mathrm{D}$ spending ( 7 cents vs 10 cents), and dividends (-2 cents vs 2 cents).

When compared to their use of other after-tax cash flow, domestic firms use more of their tax-related cash for R\&D spending (8 cents vs 5 cents) and to reduce reliance on equity financing $(6 \text { cents vs }-2 \text { cents })^{29}$. In contrast domestic firms use less of their tax-related cash (compared to other after-tax cash flow) for capital expenditures (23 cents and 31 cents), and acquisitions (6 cents vs 14 cents).

Overall we interpret the results in Table 5 as supporting $\mathrm{H} 4$ in that multinational firms allocate tax-related cash differently than domestic firms. We also interpret these results as suggesting that both multinational and domestic firms allocate tax-related cash differently from

\footnotetext{
${ }^{28}$ We find that multinational firms use a lower percentage of tax-related cash (relative to other after-tax cash flow) for acquisitions. However, because our measure of tax-related cash represents all of the cash taxes that don't covary with pretax cash flow, rather than specifically the "locked-out cash," these results are not necessarily inconsistent with the idea that "locked-out cash" is an important driver of acquisitions (Edwards, Kravet and Wilson 2016; Hanlon, Lester and Verdi 2015).

${ }^{29}$ A positive (negative) coefficient on change in equity represents a stock issuance (repurchase).
} 
other after-tax cash flow, but that these differences vary based on the firm's multinational status. In particular when compared to their use of other after-tax cash flow, multinational firms are more likely to save their tax-related cash, while domestic firms are more likely to use it to increase $\mathrm{R} \& \mathrm{D}$, and to reduce reliance on external equity financing.

Financial Constraints and the Cash Flow Allocation for Domestic vs. Multinational Firms

This section examines how financial constraints influence cash flow allocation for domestic and multinational firms. Table 6 presents results for firms facing lower financial constraints, while Table 7 presents results for firms facing higher financial constraints.

Table 6 shows that when both sets of firms are facing lower financial constraints, multinational firms (compared to domestic firms) use less of their tax-related cash for capital expenditures and more of their tax-related cash for R\&D. Table 6 also shows that when facing lower levels of financial constraint, multinational firms use less of their tax-related cash (compared to other after-tax cash flow) for dividends and more for marketable securities, while domestic firms use less of their tax-related cash (compared to other after-tax cash flow) for R\&D spending and also more for marketable securities. Specifically we find that for multinational (domestic) firms facing lower financial constraints, a one-dollar increase in tax-related cash is associated with 10 (38) cents of capital expenditures, and $9(-2)$ cents of R\&D spending. When comparing the two types of cash flow for multinational firms we find that a one-dollar increase in tax-related cash (other after-tax cash flow) is associated with -3 (3) cents more of dividends, and 36 (21) cents more of securities investment. When comparing the two types of cash flow for domestic firms we find that a one-dollar increase in tax-related cash (other after-tax cash flow) is associated with a -2 (1) cent increase in R\&D spending, and a 31 (19) cent increase in securities investment. 
Table 7 shows that when both sets of firms are facing higher financial constraints, both multinational and domestic firms use their other after-tax cash flow to finance capital expenditures and acquisitions, but neither type of firm uses a statistically significant amount of their tax-related cash flow for these purposes. When comparing multinational firms that face higher levels of financial constraint to domestic firms that face higher levels of financial constraint we find that multinational firms use less of their tax-related cash for R\&D spending and more to increase the firm's cash balance. When comparing their use of tax-related cash to their use of other after-tax cash flow, we find that multinational firms use more of their taxrelated cash for securities investment and to increase the firm's cash balance and less of their taxrelated cash for capital expenditures, acquisitions, or to reduce the reliance on external financing. In contrast domestic firms use more of their tax-related cash for R\&D spending and securities investment, and less of their tax-related cash for capital expenditures and dividends.

The specific allocations we find for domestic and multinational firms facing higher financial constraints are as follows. A one dollar increase in tax-related cash for multinational (domestic) firms is associated with a -3 (6) cent increase in capital expenditures, a -7 (0) cent increase in acquisitions, a 76 (63) cent increase in marketable securities, a 7 (20) cent increase in R\&D, a 44 (22) cent increase in the firm's cash balance, a 3 (4) cent reduction in dividends, a 5 (7) cent reduction in debt financing, and a 19 (14) cent increase in equity financing. In comparison a one dollar increase in after-tax cash flow for multinational (domestic firms) is associated with a 15 (24) cent increase in capital expenditures, an 11 (9) cent increase in acquisitions, a 34 (37) cent increase in marketable securities, a 10 (10) cent increase in R\&D, a 29 (27) cent increase in the firm's cash balance, a 1 (0) cent increase in dividends, a 0 (1) cent reduction in debt financing and a 0 (7) cent reduction in equity financing. 
Overall, we interpret the results in Table 7 as suggesting that when facing higher levels of financial constraints firms use a larger percentage of tax-related cash to preserve future investment opportunities, rather than for immediate investment. One interesting exception to these results is the apparent use of tax-related cash for R\&D spending by domestic firms that face higher levels of financial constraints. We believe this is an interesting avenue for future research.

\section{Economic Uncertainty and the Cash Flow Allocation for Domestic vs. Multinational Firms}

This section examines how economic uncertainty influences cash flow allocation for domestic and multinational firms. Table 8 presents results for firms facing lower economic uncertainty, while Table 9 presents results for firms facing higher economic uncertainty.

Table 8 shows that in times of lower economic uncertainty, multinational firms (compared to domestic firms) use less tax-related cash for capital expenditures, dividends, and to reduce reliance on equity or debt financing, and more tax-related cash for acquisitions, $R \& D$, marketable securities, to increase the firm's cash balance. Specifically we find that a one-dollar increase in tax-related cash for multinational (domestic) firms is associated with a 10 (29) cent increase in capital expenditures, a 0 (6) cent increase in dividends, a 27 (1) cent increase in acquisitions, an 11 (3) cent increase in R\&D spending, a 52 (32) cent increase in marketable securities, and a 30 (12) cent increase in the firm's cash balance. We find that for multinational firms a one-dollar increase in tax-related cash is associated with increased borrowing of 17 cents, and increased equity financing (share issuance) of 13 cents. In contrast for domestic firms a one-dollar increase in tax-related cash is associated with 8 cents less of debt, and 8 cents less of equity financing (i.e. reducing reliance on external financing). 
Table 9 shows that in times of higher economic uncertainty, multinational firms (compared to domestic firms) use less tax-related cash for dividends ( -2 cents for multinational firms vs. 2 cents for domestic firms) and marginally less tax-related cash for capital expenditures ( -2 cents for multinational firms vs. 13 cents for domestic firms). We note that the difference in capital expenditures is marginal because the $\mathrm{p}$-value of the test of the differences in coefficients for domestic (TXPD_DOM) and multinational (TXPD_MNC) firms is only 0.108 , and thus is not significant at the $10 \%$ level.

Overall the results from Tables 8 and 9 suggest that when uncertainty is low, domestic firms use tax-related cash for capital expenditures, while multinational firms use it for acquisitions and for savings. In times of higher uncertainty, the uses of cash between domestic and multinational firms are more similar, although there is some weak evidence (p-value 0.108) that domestic firms use a higher percentage of tax-related cash for investment in capital expenditures. In periods of higher and lower uncertainty both domestic and multinational firms use tax-related cash for R\&D spending, although multinational firms use substantially more of the tax-related cash for this purpose (relative to domestic firms) when economic uncertainty is lower. As with the results for financial constraints, the allocation of tax-related cash to R\&D may be a useful avenue for future research.

\section{Allocations for Loss Firms}

In our final set of analyses we investigate the allocation of tax-related cash and other after-tax cash flow for firms with losses. These firms are an important component of the economy, and thus cash flow allocations are of interest to both policy makers and researchers. ${ }^{30}$

\footnotetext{
${ }^{30}$ See for example, De Simone, Klassen and Seidman 2017; Erickson, Heitzman, and Zhang 2013; Henry and Sansing 2018; and Hopland, Lisowsky, Marden, and Schindler 2018, among others.
} 
Recall that we identify the allocation of tax-related cash through the coefficient on TXPD. After controlling for pretax income, this coefficient represents the use of cash not paid in tax. For profit firms this is straightforward, but becomes somewhat more complicated when thinking about loss firms. For a loss firm, a higher cash tax rate is good news as this represents a larger refund. ${ }^{31}$

Table 10 presents the results for a sample of loss firms. We find that a dollar of taxrelated cash is associated with reduced real investment. Instead, firms use the tax-related cash to either save or to reduce reliance on external financing. In contrast, we find that other after-tax cash flow continues to be associated with an increase in capital expenditures, acquisitions, and R\&D, albeit at lower rates than for profitable firms. These results would be consistent with firms in a tax refund situation using their refunds to pay-off debt and increase their liquidity ratios, rather than to invest in future production. We view this analysis as exploratory, and look forward to future research that examines the allocation of tax-related cash for loss firms in more detail.

\section{CONCLUSION}

Our research question investigates what firms do with cash flow freed-up by not paying taxes, which we refer to as tax-related cash. We expect that corporations will use tax-related cash differently from other after-tax cash flow due to risk of potential repayment of tax-related cash to the government. The tax payments (or lack thereof) of U.S. corporations are of increasing

\footnotetext{
31 This is best illustrated with a simple example. In our research design a firm that has \$100 of pretax income (PI) and pays $\$ 25$ of cash tax (TXPD) has positive tax-related cash when compared to a firm that has $\$ 100$ of pretax income and pays $\$ 35$ of cash tax. In this case, the firm with positive tax-related cash has a smaller absolute value of cash taxes paid (25 vs 35). In contrast a loss firm that has a pretax loss of $\$ 100$ (-100 PI) and receives a refund of $\$ 35$ (-35 TXPD) has more tax-related cash than a loss firm that has a pretax loss of $\$ 100$ ( -100 of PI) and has a refund of only $\$ 25$ (-25 of TXPD). Here the firm with more tax-related cash has a larger absolute value of TXPD. However in both cases, the firm with the more negative value of TXPD has tax-related cash. Because it is the rankordering of TXPD that matters, the OLS coefficients can be interpreted in a similar manner for both profit and loss firms.
} 
interest to the general public as well as to policymakers, with a rise in popular press coverage of taxes as well as increased scrutiny by U.S. Congress (Chen, Powers, and Stomberg 2018). However, despite a large and growing literature in accounting and finance examining the determinants and consequences of corporate tax payments, there is limited evidence on how firms use the cash freed up by not paying taxes.

Our empirical analysis utilizes the flow-of-funds model from Chang et al. (2014), which we modify by starting with pretax (instead of after-tax) operating cash flow. We also expand the analysis of the use of cash for investment by separating investment into capital expenditures, acquisitions, and securities, as well as by adding R\&D spending as a potential use of cash. Other uses of cash are for savings, dividends, and reductions in both debt and equity financing. We examine how firms allocate both tax-related cash and other after-tax cash flow. Because there may be a delay in the use of cash flow for investment, we estimate the use of cash flow over a three-year window.

We find that relative to other after-tax cash flow, firms use tax-related cash more cautiously. Over a three-year period a one-dollar increase in tax-related cash is associated with about a 36 cent increase in capital expenditures, acquisitions and R\&D spending. In comparison, a one-dollar increase in other after-tax cash flow is associated with about a 49 cent increase in these items. For our sample firms we also find that relative to a one-dollar increase in other aftertax cash flow, a one-dollar increase in tax-related cash is associated with a smaller increase in dividends and a larger increase in savings. Based on these results, firms' use of tax-related cash, on average, seems more consistent with preserving future investment opportunities rather than funding current investment. 
We also find that when compared to the allocation of other after-tax cash flow, the allocation of tax-related cash to investment is more sensitive to financial constraints. For example, we find that when financial constraints are relatively lower, a one dollar increase in tax-related cash is associated with an increase of about 40 cents in capital expenditures, acquisitions and R\&D spending, while a one dollar increase in other after-tax cash flow is associated with about a 51 cent increase in these items. In contrast, when financial constraints are relatively higher, a one-dollar increase in tax-related cash is associated with only about an 11 cent increase in capital expenditures, acquisitions, and R\&D spending, while a one-dollar increase in other after-tax cash flow is associated with about a 41 cent increase in these items. Similarly, we find that the allocation of tax-related cash to capital expenditures, acquisitions, and R\&D is also more sensitive to firm-level economic uncertainty when compared to the allocation of other after-tax cash flow.

We also provide evidence that multinational and domestic firms allocate tax-related cash differently. Specifically we find that multinational firms use a higher percentage of tax-related cash for securities investment and to increase the firm's cash balance, while domestic firms use a higher percentage for dividends and to reduce reliance on external equity financing. We fail to find evidence that for multinationals, tax-related cash is associated with less reliance on debt or to payout to shareholders, but we do find evidence that tax-related cash is associated with these uses of cash for domestic firms.

Our study is subject to several limitations. First, because our sample is focused on a broad set of firms and our measure of tax-related cash is the total cash not paid in taxes rather than the firm's "tax aggressiveness," our results may not map perfectly into other studies that examine specific subsets of firms or specific tax avoidance strategies. Second, our study focuses 
mainly on profitable firms and thus we are only able to provide limited evidence on the use of tax-related cash by loss firms, which represent an important component of the economy. Third, while we believe our estimation of the use of tax-related cash is accurate, our estimation of the use of other after-tax cash flow is potentially biased in a way that would result in an understatement of the differences in the use of tax-related cash and other after-tax cash flow (see Appendix B and the Online Appendix for an explanation of the potential bias). As such, our results should be viewed as a lower bound on the differences in the allocations of tax-related cash and other after-tax cash flow.

In spite of these limitations, we believe our paper provides important evidence on how firms allocate tax-related cash, a topic that is of interest to both academics and policymakers. Our research design incorporates the simultaneous allocation of cash flow to various uses, allowing us to identify and quantify the percentage of tax-related cash that is associated with each potential use We then compare these percentages to those of other after-tax cash flow, providing a natural benchmark. A better understanding of how firms allocate the cash flow that they don't pay in taxes, and how this allocation relates to financial constraints, economic uncertainty and multinational status also helps stakeholders in understanding why firms avoid tax. 


\section{REFERENCES:}

Bloomfield, R., M. Nelson, and E. Soltes. 2016. Gathering Data for Archival, Field, Survey, and Experimental Accounting Research. Journal of Accounting Research. 54 (2), 341-395.

Blouin, J., and L. Krull. 2009. Bringing it Home: A Study of the Incentives Surrounding the Repatriation of Foreign Earnings under the American Jobs Creation Act of 2004. Journal of Accounting Research. 47 (4), 1027-1059.

Blouin, J., Krull, L., and L. Robinson 2012. Is U.S. Multinational Dividend Repatriation Policy Influenced by Reporting Incentives? The Accounting Review 87 (5) 1463-1491.

Bodnaruk, A., T. Loughran., and B. McDonald. 2015. Using 10-K Text to Gauge Financial Constraints. Journal of Financial and Quantitative Analysis. 50, 623-646.

Campbell, J., N. Goldman., and B. Li. 2018. Do Financing Constraints Lead to Incremental Tax Planning? Evidence from Pension Protection Act of 2006. Working Paper

Campbell, S. 2018. Permanent and temporary tax avoidance as a source of financing: how to succeed where the American Jobs Creation Act of 2004 failed. Working paper, University of California Irvine.

Chang, X., S. Dasgupta, G. Wong, and J. Yao. 2014. Cash-Flow Sensitivities and the Allocation of Internal Cash Flow. Review of Financial Studies. 3628-3658.

Chen, C., and S. Lai. 2012. Financial Constraints and Tax Aggressiveness. University of Auckland and Chinese University of Hong Kong Working Paper

Chen, S., K. Powers, and B. Stomberg. 2018. Examining the role of the media in influencing corporate tax avoidance and disclosure. The Accounting Review. Forthcoming.

De Simone, L., K. Klassen, and J.K. Seidman. 2017. Unprofitable affiliates and income shifting behavior. The Accounting Review 92 (3): 113-136. 
Dyreng, S., M. Hanlon, and E. Maydew. 2018. When does tax avoidance result in tax uncertainty? The Accounting Review. Forthcoming.

Dyreng, S., M. Hanlon, E. Maydew, and J. Thornock. 2017. Changes in corporate effective tax rates over the past 25 years. Journal of Financial Economics. 124 (3) 441-463.

Edwards, A., C. Schwab, and T. Shevlin. 2016. Financial Constraints and Cash Tax Savings. The Accounting Review 91: 859-881.

Edwards, A., T. Kravet, and R. Wilson. 2016. Trapped Cash and the Profitability of Foreign Acquisitions. Contemporary Accounting Research. 33 (1), 44-77

Erickson, M., Heitzman, S., and X.F. Zhang, 2013. Tax-motivated loss shifting. The Accounting Review 88 (5): 1657-1682.

Farre-Mensa, J., and A. Ljungqvist. 2016. Do Measures of Financial Constraints Measure Financial Constraints? Review of Financial Studies 29 (2), 271-308.

Foley, C., J. Hartzell, S. Titman, and G. Twite. 2007. Why do firms hold so much cash? A taxbased explanation. Journal of Financial Economics, 86, 579-607.

Glaesar, S., and W. Guay. 2017. Identification and generalizability in accounting research: A discussion of Christensen, Floyd, Liu, and Maffet (2017). Journal of Accounting and Economics. 64 (2), 305-312.

Green, D., and J. Kerr. 2016. How Do Firms Use Cash Tax Savings: A Cross-Country Analysis. Working Paper

Greene, W. H. 2012. Econometric Analysis, $7^{\text {th }}$ Edition. Upper Saddle River: Prentice-Hall Goldman, N. 2017. The Effect of Tax Aggressiveness on Investment Efficiency. Working Paper Hanlon, M., E. Maydew and D. Saavedra. 2017. The taxman cometh: does tax uncertainty affect corporate cash holdings? Review of Accounting Studies 22: 1198-1228. 
Hanlon, M., R. Lester, and R. Verdi. 2015. The effect of repatriation tax costs on U.S. multinational investment. Journal of Financial Economics. 116 (1), 179-196.

Henry, E., and R. Sansing, 2018. Corporate tax avoidance: data truncation and loss firms, Review of Accounting Studies. 23 (3) 1042-1070.

Hopland, A.O., P. Lisowsky, M. Mardan, and D. Schindler. 2018. Flexibility in income shifting under losses. The Accounting Review 93(3): 163-183.

Jacob, M., Wentland, K., Wentland. 2018. Real Effects of Tax Uncertainty: Evidence from Firm Capital Investments. Working Paper

Kogan, L. 2004. Asset Prices and Real Investment. Journal of Financial Economics. 73: 411431.

Law, K., and L. Mills. 2015. Taxes and Financial Constraints: Evidence from Linguistic Cues. Journal of Accounting Research. 53 (4) 777-819.

Mayberry, M. 2012. Tax avoidance and investment: distinguishing the effects of capital rationing and overinvestment. Ph.D. dissertation, Texas A\&M University.

Mills, L, M. Erickson, and E. Maydew 1998. Investments in Tax Planning. Journal of the American Taxation Association. 20 (1). 1-20.

Puzder, A. 2018. You can't call the tax cuts a failure. We haven't gotten to the good part yet. Washington Post. October $25^{\text {th }}$, 2018. Available online at: https://www.washingtonpost.com/opinions/you-cant-call-the-tax-cuts-a-failure-wehavent-gotten-to-the-good-part-yet/2018/10/25/f0f26254-d7d5-11e8-aeb7ddcad4a0a54e_story.html? 


\section{APPENDIX A: VARIABLE DEFINITIONS}

\begin{tabular}{|c|c|}
\hline Variable & Definition: Compustat data items \\
\hline \multicolumn{2}{|c|}{ Independent Variables } \\
\hline CFBTRD & $\mathrm{OANCF}+\mathrm{TXPD}+\mathrm{TXBCOF}+\mathrm{EXRE}+\mathrm{XRD}$ \\
\hline CFBTRD3 & $(C F B T R D+$ lead1 $(C F B T R D)+$ lead2(CFBTRD) $) / \operatorname{ag}(\mathrm{AT})$ \\
\hline$T X P D 3$ & $-1 *(T X P D+$ lead1 $(T X P D)+$ lead2(TXPD))/lag(AT) \\
\hline PTAcc & PI - SPI - (OANCF + TXPD + TXBCOF + EXRE + XRD) \\
\hline PTAcc3 & $(P T A c c+$ lead $1(P T A c c)+\operatorname{lead} 2(P T A c c)) / \operatorname{Mag}(\mathrm{AT})$ \\
\hline SPI3 & $(\mathrm{SPI}+$ lead $1(\mathrm{SPI})+$ lead2(SPI) $) / \operatorname{lag}(\mathrm{AT})$ \\
\hline \multicolumn{2}{|c|}{ Dependent Variables } \\
\hline Investment & $-1 *$ IVNCF \\
\hline CapEx & CAPX-SPPE \\
\hline Acquisitions & AQC \\
\hline Securities & $-1 * I V N C F-$ CAPX - AQC \\
\hline$\Delta$ Cash & $\mathrm{CHECH}$ \\
\hline Div & DV \\
\hline$R \& D$ & XRD \\
\hline$\Delta D$ & DLTIS +DLTR + DLCCH + FIAO \\
\hline$\Delta E$ & SSTK - PRSTKC - DV \\
\hline Investment 3 & $($ Investment + lead $1($ Investment $)+$ lead $2($ Investment $)) / \operatorname{lag}(\mathrm{AT})$ \\
\hline CapEx3 & $($ CapEx + lead1 $($ CapEx $)+\operatorname{lead} 2($ CapEx $) / \operatorname{lag}(\mathrm{AT})$ \\
\hline Acquisitions 3 & $($ Acquisitions + lead1 $($ Acquisitions $)+$ lead2(Acqisitions $)) / \operatorname{lag}(\mathrm{AT})$ \\
\hline Securities3 & $($ Securities + lead1(Securities $)+$ lead2(Securities $)) / \operatorname{ag}(\mathrm{AT})$ \\
\hline$\Delta$ Cash3 & $(\Delta C a s h+$ lead1 $(\Delta C a s h)+$ lead2 $(\Delta C a s h)) / \operatorname{ag}(\mathrm{AT})$ \\
\hline$R \& D 3$ & $(R \& D+$ lead1 $(R \& D)+$ lead2 $(R \& D)) / \operatorname{lag}(\mathrm{AT})$ \\
\hline Div3 & $($ Div + lead1(Div) + lead2(Div))/Mag(AT) \\
\hline$\Delta D 3$ & $(\Delta D+\operatorname{lead} 1(C \Delta D)+\operatorname{lead} 2(\Delta D)) / \operatorname{lag}(\mathrm{AT})$ \\
\hline$\triangle E 3$ & $(\Delta E+$ lead1 $(\Delta E)+$ lead2 $(\Delta E)) / \operatorname{ag}(\mathrm{AT})$ \\
\hline \multicolumn{2}{|l|}{ Control Variables } \\
\hline $\operatorname{lag}(M B)$ & Market-to-Book $=\left(\mathrm{AT}+\right.$ PRCC_F $\left.{ }^{*} \mathrm{CSHO}-\mathrm{CEQ}\right) / \mathrm{AT}$ \\
\hline $\operatorname{lag}(\operatorname{Ln}(M V E))$ & Market Value of Equity $=$ PRCC_F $F^{*}$ CSHO \\
\hline $\operatorname{lag}($ SalegG $)$ & Sales Growth $=($ SALE $-\operatorname{lag} 1($ SALE $)) / \operatorname{lag}($ SALE $)$ \\
\hline $\operatorname{lag}(\operatorname{Ln}($ Assets $))$ & Price-Deflated Book Assets = AT/GDP_Deflator \\
\hline $\operatorname{lag}($ Tangibility) & Tangibility $=$ PPENT/AT \\
\hline $\operatorname{lag}($ Leverage $)$ & Leverage $=(\mathrm{DLC}+\mathrm{DLTT}) / \mathrm{AT}$ \\
\hline $\operatorname{lag}($ CarryForward $)$ & Tax Loss Carry Forward $=$ TLCF $/ A T$ \\
\hline $\operatorname{lag}(\operatorname{Inv})$ & Investment $=-1 * \mathrm{IVNCF} / \mathrm{lag}(\mathrm{AT})$ \\
\hline $\operatorname{lag}(R \& D)$ & Research \& Development $=$ XRD/lag(AT) \\
\hline $\operatorname{lag}($ RetEarn $)$ & RetEarn $=$ REUNA/AT \\
\hline $\operatorname{lag}(P T R O A)$ & $P T R O A=(\mathrm{PI}-\mathrm{IDIT}) / \operatorname{lag}(\mathrm{AT})$ \\
\hline
\end{tabular}




\section{APPENDIX B: INTERPRETATION OF REGRESSION COEFFICIENTS}

Define "tax savings" (TS) for a firm as equal to r*PCF - TXPD, where PCF is pretax

cash flow, TXPD is cash taxes paid, and $\mathrm{r}$ is a theoretical tax rate used by the firm's manager, but unobservable to a researcher. ${ }^{32}$ The firm's after-tax cash flow (ACF) is given by:

$$
\begin{aligned}
\mathrm{ACF} & =\mathrm{PCF}-\mathrm{TXPD} \\
& =\mathrm{PCF}-\mathrm{r} * \mathrm{PCF}+\left[\mathrm{r}^{*} \mathrm{PCF}-\mathrm{TXPD}\right] \\
& =\mathrm{PCF}(1-\mathrm{r})+\mathrm{TS}
\end{aligned}
$$

where $\mathrm{PCF}(1-\mathrm{r})$ is cash flow without tax savings (CFWTS).

Assume that each year the manager invests the following amount in real assets (INV):

$$
\mathrm{INV}=\mathrm{w}^{*} \mathrm{CFWTS}+\mathrm{z}^{*} \mathrm{TS}+\mathrm{e}
$$

where $\mathrm{w}$ and $\mathrm{z}$ are rates between 0 and 1 , and $\mathrm{e}$ is a mean zero random amount that varies each year. ${ }^{33}$ This investment amount is equivalent to:

$$
\mathrm{INV}=\mathrm{w}^{*} \mathrm{PCF}-\mathrm{w}^{*}(\mathrm{r} * \mathrm{PCF})+\mathrm{z} * \mathrm{TS}+\mathrm{e} .
$$

In the Online Appendix we use simulated data randomly generated from populations with known parameters to demonstrate that coefficients from the following OLS regression:

$$
\mathrm{INV}=\beta_{0}+\beta_{1} * \mathrm{PCF}+\beta_{2} * \mathrm{TXPD}+\varepsilon
$$

have the following characteristics:

1. The coefficient $\beta_{2}$ is equal to the rate $\mathrm{z}$ (the percentage of tax savings that the manager invests in real assets);

2. If $\mathrm{w}=\mathrm{z}$, the coefficient $\beta_{1}$ is equal to the rate $\mathrm{w}$ (the percentage of cash flow without tax savings that the manager invests in real assets);

\footnotetext{
${ }^{32}$ The rate $\mathrm{r}$ may be the statutory tax rate, the firm's long-run effective tax rate, or any other rate the manager uses in making decisions about how to invest the firm's cash flow.

${ }^{33}$ Note that $\mathrm{w}$ and $\mathrm{z}$ may be equal.
} 
3. If $\mathrm{w} \neq \mathrm{z}$, the coefficient $\beta_{1}$ will be biased relative to the rate $\mathrm{w}$; and

4. The bias in $\beta_{1}$ is always such that, regardless of whether $\beta_{2}$ is larger or smaller than $\beta_{1}$, the difference between $\beta_{2}$ and $\beta_{1}$ is always less than the difference between $\mathrm{z}$ and $\mathrm{w}$ (i.e., the difference in the regression coefficients is a lower bound on the difference in the true investment weights). 
TABLE 1: Descriptive statistics

\begin{tabular}{|c|c|c|c|c|c|c|c|}
\hline Variable & Standard Dev. & Mean & $5^{\text {th }}$ Pctile & $25^{\text {th }}$ Pctile & 50 $^{\text {th }}$ Pctile & $7^{\text {th }}$ Pctile & 95 ${ }^{\text {th }}$ Pctile \\
\hline \multicolumn{8}{|c|}{ Panel A: Variables Measured Over One Year (67,981 observations) } \\
\hline ATCF & 0.101 & 0.142 & 0.000 & 0.077 & 0.128 & 0.193 & 0.332 \\
\hline CFBTRD & 0.111 & 0.167 & 0.014 & 0.093 & 0.151 & 0.227 & 0.375 \\
\hline$T X P D$ & 0.028 & -0.026 & -0.084 & -0.039 & -0.017 & -0.003 & 0.000 \\
\hline Investment & 0.100 & 0.094 & -0.016 & 0.030 & 0.070 & 0.135 & 0.295 \\
\hline CapEx & 0.070 & 0.067 & 0.005 & 0.022 & 0.045 & 0.085 & 0.209 \\
\hline Acquisitions & 0.057 & 0.022 & 0.000 & 0.000 & 0.000 & 0.011 & 0.139 \\
\hline Securities & 0.057 & 0.005 & -0.075 & -0.006 & 0.000 & 0.011 & 0.104 \\
\hline$R \& D$ & 0.048 & 0.027 & 0.000 & 0.000 & 0.000 & 0.031 & 0.139 \\
\hline$\triangle$ Cash & 0.067 & 0.013 & -0.084 & -0.013 & 0.003 & 0.032 & 0.135 \\
\hline Div & 0.023 & 0.014 & 0.000 & 0.000 & 0.000 & 0.019 & 0.059 \\
\hline$\Delta E$ & 0.055 & -0.001 & -0.080 & -0.008 & 0.000 & 0.005 & 0.068 \\
\hline$\Delta D$ & 0.078 & 0.006 & -0.106 & -0.029 & -0.001 & 0.026 & 0.154 \\
\hline PTAcc & 0.086 & -0.060 & -0.208 & -0.104 & -0.057 & -0.016 & 0.077 \\
\hline SPI & 0.017 & -0.003 & -0.030 & -0.004 & 0.000 & 0.000 & 0.013 \\
\hline \multicolumn{8}{|c|}{ Panel B: Variables Measured Over Three Years $(53,557$ observations) } \\
\hline ATCF3 & 0.318 & 0.473 & 0.082 & 0.263 & 0.411 & 0.615 & 1.087 \\
\hline CFBTRD3 & 0.359 & 0.562 & 0.123 & 0.315 & 0.491 & 0.732 & 1.256 \\
\hline Investment3 & 0.089 & -0.090 & -0.271 & -0.129 & -0.066 & -0.022 & 0.000 \\
\hline CapEx3 & 0.325 & 0.342 & 0.004 & 0.128 & 0.258 & 0.467 & 0.990 \\
\hline Acquisitions3 & 0.233 & 0.226 & 0.025 & 0.080 & 0.155 & 0.282 & 0.681 \\
\hline Securities3 & 0.194 & 0.100 & 0.000 & 0.000 & 0.011 & 0.113 & 0.489 \\
\hline Investment 3 & 0.146 & 0.017 & -0.174 & -0.027 & 0.000 & 0.033 & 0.269 \\
\hline$R \& D 3$ & 0.164 & 0.089 & 0.000 & 0.000 & 0.000 & 0.102 & 0.459 \\
\hline$\Delta \operatorname{Cash} 3$ & 0.134 & 0.044 & -0.104 & -0.012 & 0.011 & 0.069 & 0.293 \\
\hline $\operatorname{Div} 3$ & 0.057 & 0.041 & 0.000 & 0.000 & 0.015 & 0.065 & 0.166 \\
\hline$\Delta E 3$ & 0.173 & 0.000 & -0.242 & -0.048 & 0.000 & 0.021 & 0.256 \\
\hline$\triangle D 3$ & 0.199 & 0.044 & -0.202 & -0.055 & 0.000 & 0.105 & 0.415 \\
\hline PTAcc3 & 0.249 & -0.225 & -0.690 & -0.330 & -0.193 & -0.086 & 0.119 \\
\hline SPI3 & 0.055 & -0.019 & -0.117 & -0.031 & -0.005 & 0.000 & 0.036 \\
\hline \multicolumn{8}{|c|}{ Panel C: Additional Control variables (For main sample of 53,557 observations) } \\
\hline $\operatorname{lag}(M B)$ & 1.018 & 1.716 & 0.801 & 1.083 & 1.413 & 1.987 & 3.686 \\
\hline $\operatorname{lag}(\ln (M V E))$ & 2.363 & 6.066 & 2.105 & 4.370 & 6.119 & 7.719 & 9.973 \\
\hline $\operatorname{lag}(\operatorname{Sale} G)$ & 0.274 & 0.141 & -0.175 & 0.005 & 0.091 & 0.210 & 0.610 \\
\hline $\operatorname{lag}(\ln ($ Assets $))$ & 2.184 & 11.051 & 7.492 & 9.501 & 10.981 & 12.563 & 14.826 \\
\hline $\operatorname{lag}($ Tangibility) & 0.228 & 0.312 & 0.035 & 0.129 & 0.255 & 0.448 & 0.781 \\
\hline $\operatorname{lag}($ Leverage $)$ & 0.183 & 0.223 & 0.000 & 0.062 & 0.205 & 0.337 & 0.562 \\
\hline $\operatorname{lag}($ CarryForward $)$ & 0.241 & 0.071 & 0.000 & 0.000 & 0.000 & 0.019 & 0.389 \\
\hline $\operatorname{lag}($ Invst $)$ & 0.099 & 0.086 & -0.028 & 0.028 & 0.066 & 0.125 & 0.281 \\
\hline $\operatorname{lag}(R \& D)$ & 0.043 & 0.024 & 0.000 & 0.000 & 0.000 & 0.028 & 0.121 \\
\hline $\operatorname{lag}($ RetEarn $)$ & 0.560 & 0.145 & -0.678 & 0.040 & 0.223 & 0.411 & 0.699 \\
\hline $\operatorname{lag}(P T R O A)$ & 0.100 & 0.073 & -0.084 & 0.030 & 0.075 & 0.126 & 0.223 \\
\hline
\end{tabular}


TABLE 2: Allocation of Tax-Related Cash and Other After-Tax Cash Flow

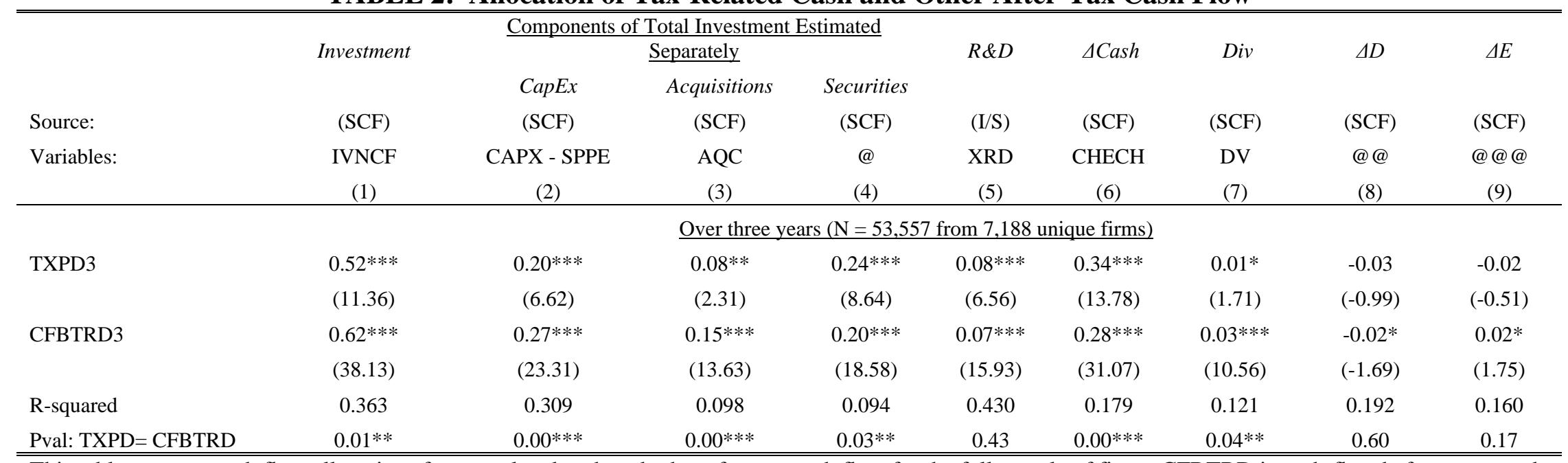

This table presents cash flow allocations for tax-related cash and other after-tax cash flow for the full sample of firms. CFBTRD is cash-flow before taxes and R\&D (i.e. pretax cash flow), as defined in Appendix A. The coefficient on TXPD (CFBTRD) represents the allocation of tax-related cash (other after-tax cash flow). Source: SCF = Statement of Cash Flow; I/S = Income Statement. @: Siv = IVNCF - (CAPX - SPPE) - AQC; @ @ : $\Delta D=$ DLTIS - DLTR + FIAO;

@@@ $₫ \mathrm{E}=\mathrm{SSTK}-\mathrm{PRSTKC} . * * *, * *$, and * represent significance at the 10\%, 5\%, and 1\% level or better, using two-tailed tests, where standard errors are clustered by firm. Pval: TXPD=PCF represents the p-value from a test of whether the coefficients on TXPD and PCF are statistically different from each other 
TABLE 3: Allocations Based on Relative Financial Constraints

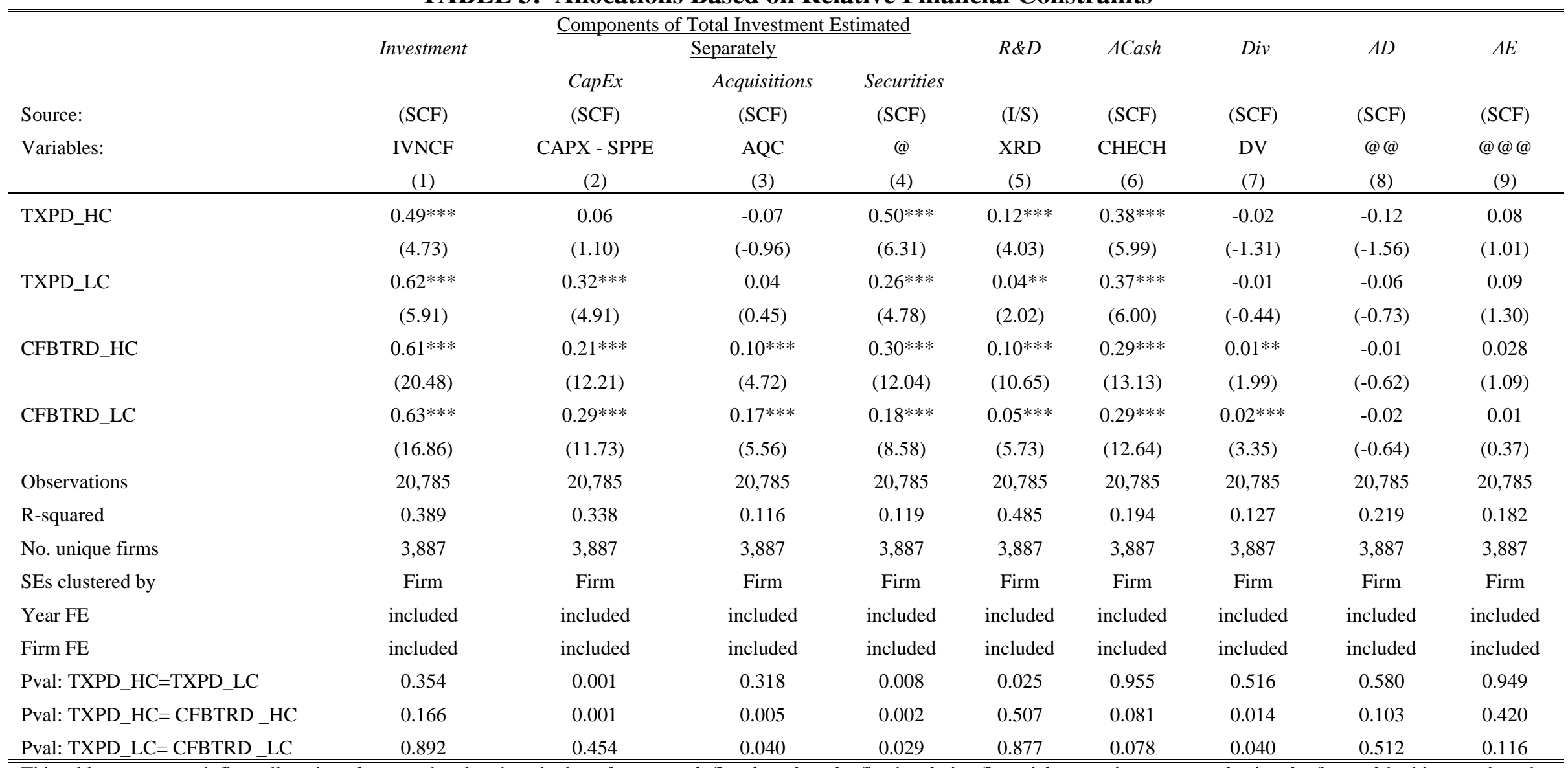

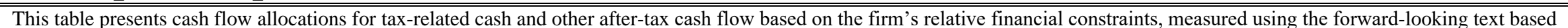
measure from Bodnaruk, Loughran, and McDonald (2015). Numbers may not equal exactly one due to rounding. HC represents relatively higher financial constraints (top tercile), LC represents relatively lower financial constraints (lowest tercile). CFBTRD is cash-flow before taxes and R\&D (i.e. pretax cash flow), as defined in Appendix A. The coefficients on

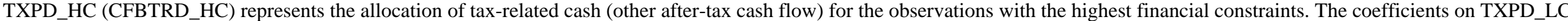

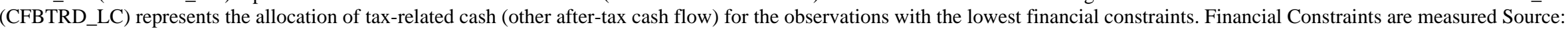
$\mathrm{SCF}=$ Statement of Cash Flow; I/S = Income Statement. @ : Siv= IVNCF - (CAPX - SPPE) - AQC; @ @ : $\triangle \mathrm{D}=\mathrm{DLTIS}-\mathrm{DLTR}+\mathrm{FIAO}$; @ @ @ : $\Delta \mathrm{E}=\mathrm{SSTK}-\mathrm{PRSTKC}$.***,**, and *

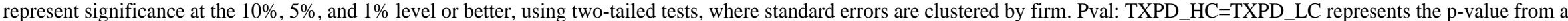
test of whether the coefficients on TXPD_HC and TXPD_LC are statistically different from each other, etc. 
TABLE 4: Allocations Based on Economic Uncertainty (Stock Return Volatility)

\begin{tabular}{|c|c|c|c|c|c|c|c|c|c|}
\hline \multicolumn{10}{|c|}{$\begin{array}{ll} & \text { Components of Total Investment Estimated } \\
\end{array}$} \\
\hline \multirow{4}{*}{$\begin{array}{l}\text { Source: } \\
\text { Variables: }\end{array}$} & \multirow{2}{*}{$\begin{array}{l}\text { Investment } \\
\text { (SCF) }\end{array}$} & \multicolumn{3}{|c|}{ Separately } & \multirow{2}{*}{$\begin{array}{l}R \& D \\
(\mathrm{I} / \mathrm{S})\end{array}$} & \multirow{2}{*}{$\begin{array}{l}\triangle \text { Cash } \\
\text { (SCF) }\end{array}$} & \multirow{2}{*}{$\begin{array}{c}\text { Div } \\
\text { (SCF) }\end{array}$} & \multirow{2}{*}{$\begin{array}{c}\Delta D \\
(\mathrm{SCF})\end{array}$} & \multirow{2}{*}{$\begin{array}{c}\Delta E \\
(\mathrm{SCF})\end{array}$} \\
\hline & & $\begin{array}{l}\text { CapEx } \\
\text { (SCF) }\end{array}$ & $\begin{array}{c}\text { Acquisitions } \\
\text { (SCF) }\end{array}$ & $\begin{array}{c}\text { Securities } \\
\text { (SCF) }\end{array}$ & & & & & \\
\hline & IVNCF & CAPX - SPPE & AQC & @ & XRD & $\mathrm{CHECH}$ & DV & @@ & @@@ \\
\hline & (1) & $(2)$ & (3) & (4) & (5) & (6) & $(7)$ & $(8)$ & $(9)$ \\
\hline \multirow[t]{2}{*}{ TXPD_HV } & $0.34 * * *$ & 0.06 & 0.05 & $0.23 * * *$ & $0.08 * * *$ & $0.43 * * *$ & 0.01 & $-0.15 * * *$ & -0.000 \\
\hline & $(4.74)$ & $(1.38)$ & $(1.04)$ & $(4.85)$ & $(3.57)$ & (10.38) & $(0.73)$ & $(-3.10)$ & $(-0.01)$ \\
\hline \multirow[t]{2}{*}{ TXPD_LV } & $0.78 * * *$ & $0.18^{* * *}$ & $0.18^{* *}$ & $0.43 * * *$ & $0.09 * * *$ & $0.18 * * *$ & 0.03 & 0.10 & -0.03 \\
\hline & $(8.25)$ & $(3.08)$ & $(2.48)$ & $(8.58)$ & $(5.50)$ & $(4.89)$ & $(1.40)$ & $(1.55)$ & $(-0.55)$ \\
\hline \multirow[t]{2}{*}{ CFBTRD_HV } & $0.58 * * *$ & $0.23 * * *$ & $0.12 * * *$ & $0.23 * * *$ & $0.10 * * *$ & $0.34 * * *$ & $0.02 * * *$ & $-0.05^{* * *}$ & $0.08 * * *$ \\
\hline & $(24.63)$ & $(15.95)$ & $(7.73)$ & $(13.81)$ & (13.433) & $(24.46)$ & $(5.45)$ & $(-3.67)$ & $(4.85)$ \\
\hline \multirow[t]{2}{*}{ CFBTRD_LV } & $0.71 * * *$ & $0.22 * * *$ & $0.28 * * *$ & $0.21 * * *$ & $0.06 * * *$ & $0.16^{* * *}$ & $0.05^{* * *}$ & 0.04 & $-0.05 * * *$ \\
\hline & $(19.71)$ & $(10.50)$ & $(9.45)$ & $(11.02)$ & $(9.37)$ & $(10.83)$ & $(6.59)$ & $(1.46)$ & $(-2.79)$ \\
\hline Observations & 30,772 & 30,772 & 30,772 & 30,772 & 30,772 & 30,772 & 30,772 & 30,772 & 30,772 \\
\hline R-squared & 0.368 & 0.311 & 0.112 & 0.108 & 0.456 & 0.203 & 0.179 & 0.208 & 0.187 \\
\hline No. unique firms & 5,548 & 5,548 & 5,548 & 5,548 & 5,548 & 5,548 & 5,548 & 5,548 & 5,548 \\
\hline SEs clustered by & Firm & Firm & Firm & Firm & Firm & Firm & Firm & Firm & Firm \\
\hline Year FE & included & included & included & included & included & included & included & included & included \\
\hline Firm FE & included & included & included & included & included & included & included & included & included \\
\hline Pval: TXPD_HV=TXPD_LV & 0.000 & 0.100 & 0.120 & 0.002 & 0.593 & 0.000 & 0.371 & 0.001 & 0.699 \\
\hline Pval: TXPD_HV=CFBTRD_HV & 0.000 & 0.000 & 0.070 & 0.971 & 0.433 & 0.007 & 0.265 & 0.013 & 0.046 \\
\hline Pval: TXPD_LV=CFBTRD_LV & 0.342 & 0.289 & 0.057 & 0.000 & 0.013 & 0.618 & 0.187 & 0.194 & 0.481 \\
\hline
\end{tabular}

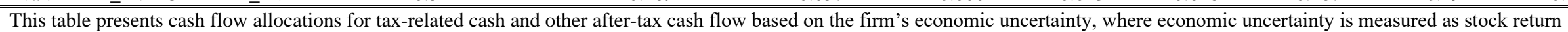

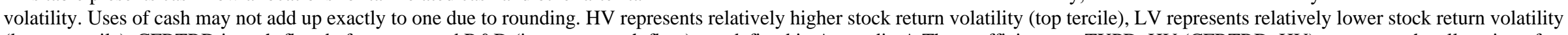

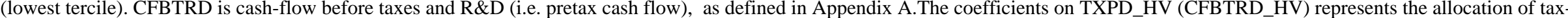

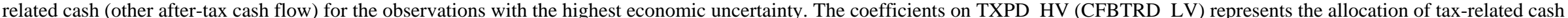

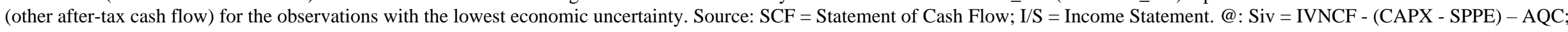

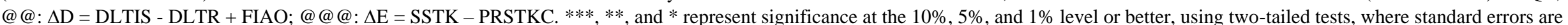
clustered by firm. Pval: TXPD_HV=TXPD_LV represents the p-value from a test of whether the coefficients on TXPD_HV and TXPD_LV are statistically different from each other, etc. 
TABLE 5: Allocation of Cash Flow for Domestic and Multinational Firms

\begin{tabular}{|c|c|c|c|c|c|c|c|c|c|}
\hline & & Components & tal Investmen & imated & & & & & \\
\hline & Investment & & eparately & & $R \& D$ & $\triangle$ Cash & Div & $\Delta D$ & $\Delta E$ \\
\hline Source: & (SCF) & $\begin{array}{l}\text { CapEx } \\
(\mathrm{SCF})\end{array}$ & $\begin{array}{c}\text { Acquisitions } \\
\text { (SCF) }\end{array}$ & $\begin{array}{c}\text { Securities } \\
\text { (SCF) }\end{array}$ & $(\mathrm{I} / \mathrm{S})$ & $(\mathrm{SCF})$ & (SCF) & (SCF) & (SCF) \\
\hline Variables: & IVNCF & CAPX - SPPE & AQC & @ & XRD & CHECH & DV & @@ & @@@ \\
\hline & (1) & $(2)$ & $(3)$ & $(4)$ & (5) & (6) & $(7)$ & $(8)$ & $(9)$ \\
\hline TXPD_MNC & $0.62 * * *$ & $0.16^{* * *}$ & 0.07 & $0.39 * * *$ & $0.07 * * *$ & $0.41 * * *$ & -0.02 & -0.00 & $0.09 *$ \\
\hline & $(8.55)$ & $(3.88)$ & $(1.29)$ & $(8.15)$ & $(3.03)$ & $(9.89)$ & $(-1.22)$ & $(-0.05)$ & $(1.72)$ \\
\hline TXPD_DOM & $0.45^{* * *}$ & $0.23 * * *$ & $0.06^{*}$ & $0.17 * * *$ & $0.08 * * *$ & $0.31 * * *$ & $0.03 * * *$ & $-0.07 *$ & $-0.06^{*}$ \\
\hline & $(8.24)$ & $(5.77)$ & (1.70) & $(5.27)$ & $(6.65)$ & (10.82) & $(2.81)$ & $(-1.77)$ & $(-1.77)$ \\
\hline CFBTRD_MNC & $0.62 * * *$ & $0.21 * * *$ & $0.18 * * *$ & $0.24 * * *$ & $0.10 * * *$ & $0.29 * * *$ & $0.02 * * *$ & -0.00 & 0.02 \\
\hline & $(25.58)$ & (14.99) & $(9.40)$ & (13.79) & $(13.20)$ & (18.89) & $(4.43)$ & $(-0.03)$ & $(-1.34)$ \\
\hline CFBTRD_DOM & $0.62 * * *$ & $0.31 * * *$ & $0.14 * * *$ & $0.17 * * *$ & $0.05 * * *$ & $0.28 * * *$ & $0.03 * * *$ & $-0.03 * *$ & 0.02 \\
\hline & (30.99) & $(20.37)$ & $(10.61)$ & (14.59) & (11.53) & $(26.20)$ & $(10.33)$ & $(-2.51)$ & $(-1.46)$ \\
\hline Observations & 53,557 & 53,557 & 53,557 & 53,557 & 53,557 & 53,557 & 53,557 & 53,557 & 53,557 \\
\hline R-squared & 0.366 & 0.317 & 0.102 & 0.098 & 0.447 & 0.180 & 0.125 & 0.196 & 0.167 \\
\hline No. unique firms & 7,188 & 7,188 & 7,188 & 7,188 & 7,188 & 7,188 & 7,188 & 7,188 & 7,188 \\
\hline Clustered SE & Firm & Firm & Firm & Firm & Firm & Firm & Firm & Firm & Firm \\
\hline Year FE & included & included & included & included & included & included & included & included & Included \\
\hline Firm FE & included & included & included & included & included & included & included & included & Included \\
\hline Pval: TXPD_MNC=TXPD_DOM & 0.050 & 0.220 & 0.880 & 0.000 & 0.463 & 0.024 & 0.004 & 0.277 & 0.012 \\
\hline Pval: TXPD_MNC $=$ CFBTRD_MNC & 0.985 & 0.144 & 0.025 & 0.000 & 0.072 & 0.000 & 0.002 & 0.962 & 0.110 \\
\hline Pval: TXPD_DOM=CFBTRD_DOM & 0.000 & 0.006 & 0.010 & 0.826 & 0.003 & 0.251 & 0.505 & 0.248 & 0.005 \\
\hline
\end{tabular}

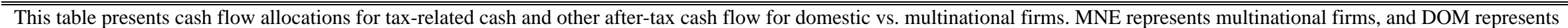

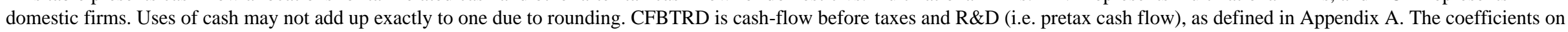

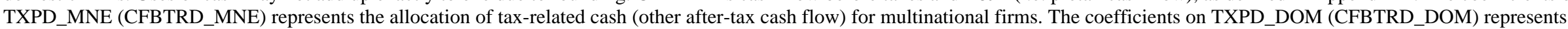

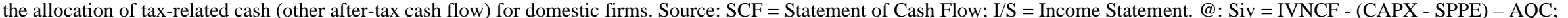

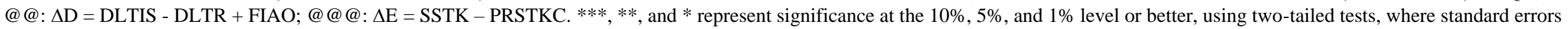

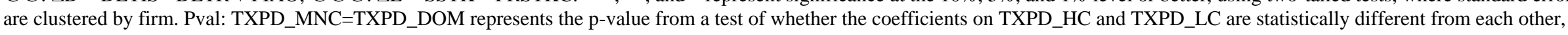
etc. 
TABLE 6: Allocation of Cash Flow for Domestic and Multinational Firms Facing Lower Financial Constraints

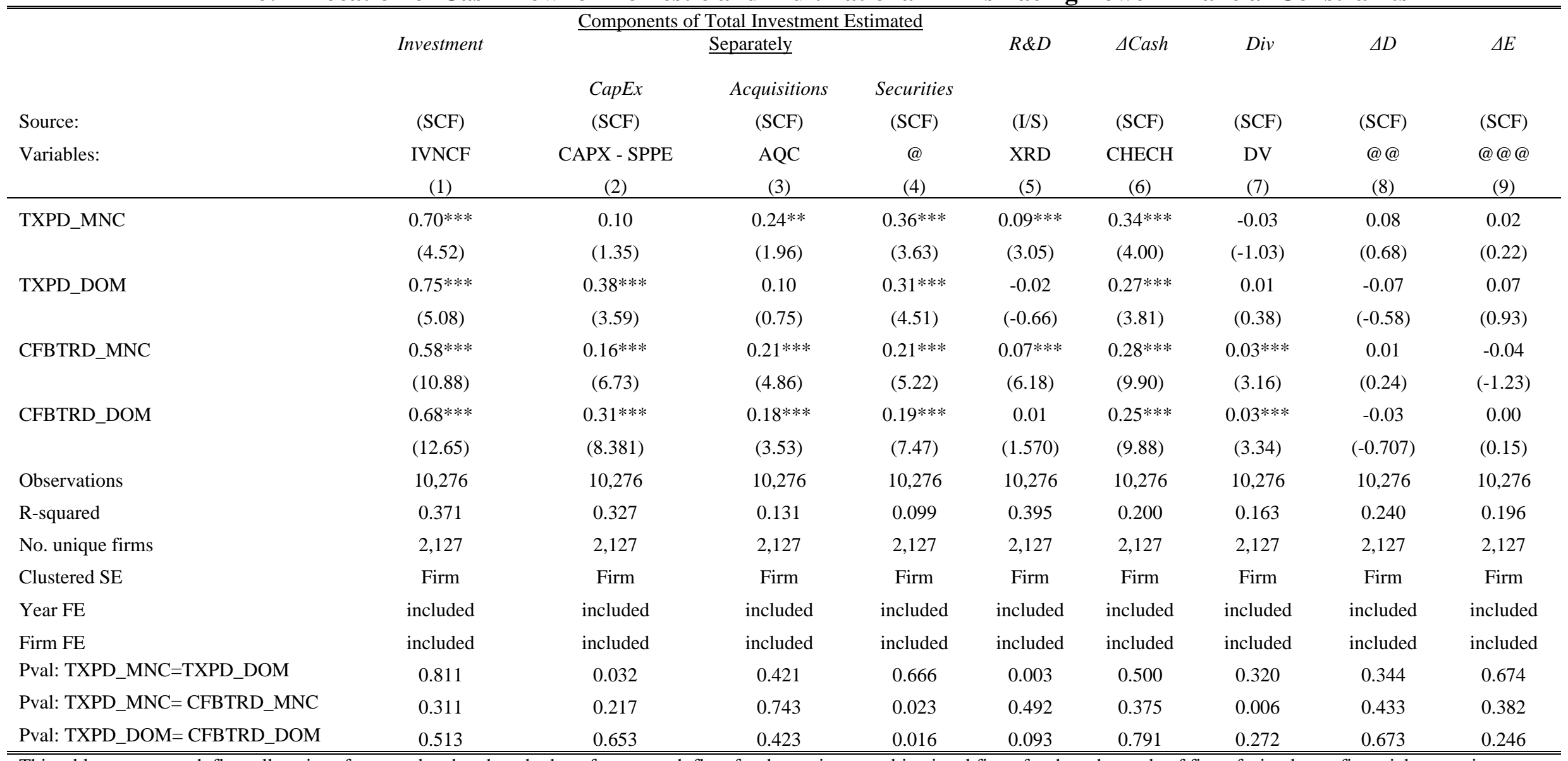

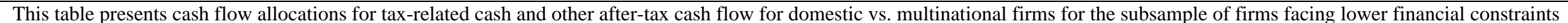

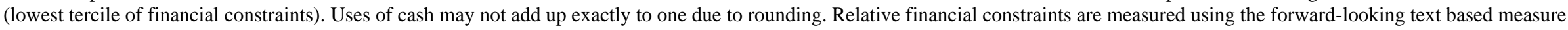

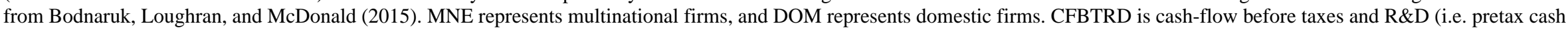
flow), as defined in Appendix A. The coefficients on TXPD_MNE (CFBTRD_MNE) represents the allocation of tax-related cash (other after-tax cash flow) for multinational firms. The

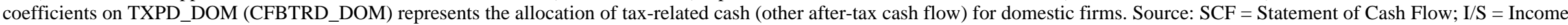

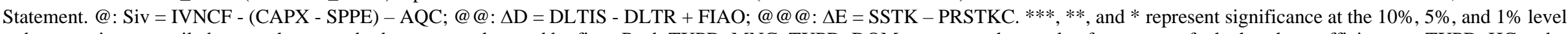

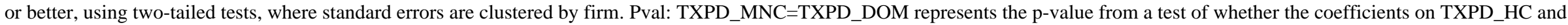
TXPD_LC are statistically different from each other, etc. 
TABLE 7: Allocation of Cash Flow for Domestic and Multinational Firms Facing Higher Financial Constraints

\begin{tabular}{|c|c|c|c|c|c|c|c|c|c|}
\hline \multicolumn{10}{|c|}{ Components of Total Investment Estimated } \\
\hline \multirow{4}{*}{$\begin{array}{l}\text { Source: } \\
\text { Variables: }\end{array}$} & Investment & \multicolumn{3}{|c|}{$\underline{\text { Separately }}$} & \multirow{2}{*}{$\begin{array}{l}R \& D \\
(\mathrm{I} / \mathrm{S})\end{array}$} & \multirow{2}{*}{$\begin{array}{l}\triangle \text { Cash } \\
\text { (SCF) }\end{array}$} & \multirow{2}{*}{$\begin{array}{c}\text { Div } \\
\text { (SCF) }\end{array}$} & \multirow{2}{*}{$\begin{array}{c}\Delta D \\
(\mathrm{SCF})\end{array}$} & \multirow{2}{*}{$\begin{array}{c}\Delta E \\
(\mathrm{SCF})\end{array}$} \\
\hline & $(\mathrm{SCF})$ & $\begin{array}{l}\text { CapEx } \\
(\mathrm{SCF})\end{array}$ & $\begin{array}{c}\text { Acquisitions } \\
\text { (SCF) }\end{array}$ & $\begin{array}{c}\text { Securities } \\
\text { (SCF) }\end{array}$ & & & & & \\
\hline & IVNCF & CAPX - SPPE & AQC & $@$ & XRD & $\mathrm{CHECH}$ & DV & @@ & @@@ \\
\hline & (1) & $(2)$ & (3) & $(4)$ & $(5)$ & $(6)$ & $(7)$ & $(8)$ & (9) \\
\hline \multirow[t]{2}{*}{ TXPD_MNC } & $0.66^{* * *}$ & -0.03 & -0.07 & $0.76^{* * *}$ & 0.07 & $0.44 * * *$ & -0.03 & -0.05 & $0.19 *$ \\
\hline & $(4.94)$ & $(-0.54)$ & $(-0.61)$ & $(7.07)$ & $(1.56)$ & $(4.62)$ & $(-0.780)$ & $(-0.49)$ & $(1.85)$ \\
\hline \multirow[t]{2}{*}{ TXPD_DOM } & $0.69 * * *$ & 0.06 & -0.00 & $0.63 * * *$ & $0.20 * * *$ & $0.22 * *$ & $-0.04 *$ & -0.07 & 0.14 \\
\hline & $(4.46)$ & $(0.73)$ & $(-0.02)$ & $(5.53)$ & (4.79) & $(2.52)$ & $(-1.94)$ & $(-0.66)$ & $(1.11)$ \\
\hline \multirow[t]{2}{*}{ CFBTRD_MNC } & $0.60 * * *$ & $0.15^{* * *}$ & $0.11 * *$ & $0.34 * * *$ & $0.10 * * *$ & $0.29 * * *$ & 0.01 & 0.00 & 0.00 \\
\hline & (14.61) & $(9.36)$ & $(3.23)$ & $(9.38)$ & (7.18) & $(8.47)$ & $(0.97)$ & $(0.01)$ & $(0.04)$ \\
\hline \multirow[t]{2}{*}{ CFBTRD_DOM } & $0.70 * * *$ & $0.24 * * *$ & $0.09 * * *$ & $0.37 * * *$ & $0.10 * * *$ & $0.27 * * *$ & 0.00 & 0.01 & 0.07 \\
\hline & (14.68) & $(8.62)$ & $(3.17)$ & (9.17) & (7.43) & $(9.88)$ & $(0.41)$ & $(0.19)$ & $(1.61)$ \\
\hline Observations & 10,276 & 10,276 & 10,276 & 10,276 & 10,276 & 10,276 & 10,276 & 10,276 & 10,279 \\
\hline R-squared & 0.381 & 0.343 & 0.106 & 0.170 & 0.511 & 0.206 & 0.122 & 0.228 & 0.201 \\
\hline No. unique firms & 2,570 & 2,570 & 2,570 & 2,570 & 2,570 & 2,570 & 2,570 & 2,570 & 2,570 \\
\hline Clustered SE & Firm & Firm & Firm & Firm & Firm & Firm & Firm & Firm & Firm \\
\hline Year FE & included & included & included & included & included & included & included & included & included \\
\hline Firm FE & included & included & included & included & included & included & included & included & included \\
\hline Pval: TXPD_MNC=TXPD_DOM & 0.863 & 0.345 & 0.653 & 0.407 & 0.031 & 0.073 & 0.767 & 0.886 & 0.719 \\
\hline Pval: TXPD_MNC $=$ CFBTRD_MNC & 0.609 & 0.001 & 0.054 & 0.000 & 0.352 & 0.039 & 0.120 & 0.548 & 0.023 \\
\hline Pval: TXPD_DOM=CFBTRD_DOM & 0.930 & 0.006 & 0.301 & 0.004 & 0.002 & 0.475 & 0.012 & 0.398 & 0.483 \\
\hline
\end{tabular}

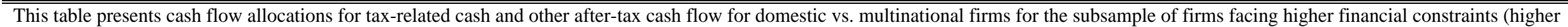

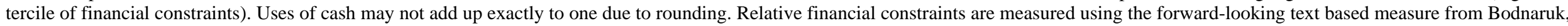

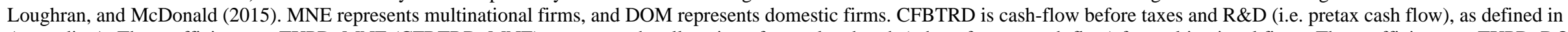

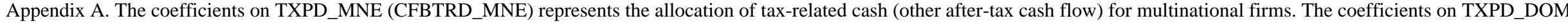

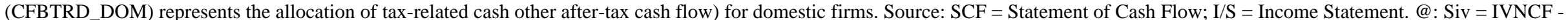

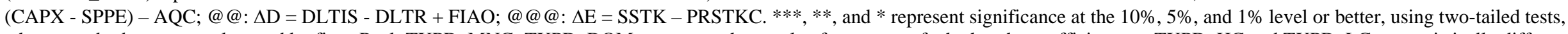

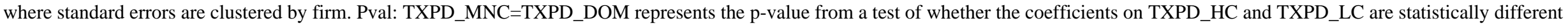
from each other, etc. 
TABLE 8: Allocation of Cash Flow for Domestic and Multinational Firms In Times of Lower Economic Uncertainty

\begin{tabular}{|c|c|c|c|c|c|c|c|c|c|}
\hline \multicolumn{10}{|c|}{ Components of Total Investment Estimated } \\
\hline \multirow{4}{*}{$\begin{array}{l}\text { Source: } \\
\text { Variables: }\end{array}$} & \multirow{2}{*}{$\begin{array}{c}\text { Investment } \\
\text { (SCF) }\end{array}$} & \multicolumn{3}{|c|}{ Separately } & \multirow{2}{*}{$\begin{array}{l}R \& D \\
(\mathrm{I} / \mathrm{S})\end{array}$} & \multirow{2}{*}{$\begin{array}{l}\triangle \text { Cash } \\
\text { (SCF) }\end{array}$} & \multirow{2}{*}{$\begin{array}{c}\text { Div } \\
\text { (SCF) }\end{array}$} & \multirow{2}{*}{$\begin{array}{c}\Delta D \\
(\mathrm{SCF})\end{array}$} & \multirow{2}{*}{$\begin{array}{c}\Delta E \\
\text { (SCF) }\end{array}$} \\
\hline & & $\begin{array}{l}\text { CapEx } \\
(\mathrm{SCF})\end{array}$ & $\begin{array}{c}\text { Acquisitions } \\
\text { (SCF) }\end{array}$ & $\begin{array}{l}\text { Securities } \\
\text { (SCF) }\end{array}$ & & & & & \\
\hline & IVNCF & CAPX - SPPE & AQC & $@$ & XRD & $\mathrm{CHECH}$ & DV & @@ & @@@ \\
\hline & $(1)$ & $(2)$ & $(3)$ & $(4)$ & $(5)$ & $(6)$ & $(7)$ & $(8)$ & (9) \\
\hline \multirow[t]{2}{*}{ TXPD_MNC } & $0.89 * * *$ & 0.10 & $0.27 * * *$ & $0.52 * * *$ & $0.11 * * *$ & $0.30 * * *$ & 0.00 & $0.17^{*}$ & 0.13 \\
\hline & $(6.83)$ & $(1.12)$ & $(2.73)$ & $(6.84)$ & $(4.43)$ & $(5.42)$ & $(0.13)$ & $(1.84)$ & $(1.63)$ \\
\hline \multirow[t]{2}{*}{ TXPD_DOM } & $0.62 * * *$ & $0.29 * * *$ & 0.01 & $0.32 * * *$ & $0.03 * *$ & $0.12 * * *$ & $0.06^{* * *}$ & -0.08 & -0.08 \\
\hline & $(5.21)$ & $(3.44)$ & $(0.16)$ & $(5.52)$ & $(2.37)$ & $(2.59)$ & $(2.63)$ & $(-1.01)$ & $(-1.33)$ \\
\hline \multirow[t]{2}{*}{ CFBTRD_MNC } & $0.70 * * *$ & $0.17 * * *$ & $0.30 * * *$ & $0.23 * * *$ & $0.08 * * *$ & $0.19 * * *$ & $0.04 * * *$ & 0.05 & -0.04 \\
\hline & (14.47) & $(5.86)$ & $(7.37)$ & $(7.33)$ & $(8.60)$ & $(8.44)$ & $(4.57)$ & $(1.32)$ & $(-1.23)$ \\
\hline \multirow[t]{2}{*}{ CFBTRD_DOM } & $0.68 * * *$ & $0.32 * * *$ & $0.16^{* * *}$ & $0.20 * * *$ & $0.03 * * *$ & $0.16^{* * *}$ & $0.06^{* * *}$ & $-0.05^{*}$ & -0.03 \\
\hline & (14.08) & $(9.55)$ & $(5.01)$ & $(8.67)$ & $(5.42)$ & (7.64) & $(5.75)$ & $(-1.72)$ & $(-1.09)$ \\
\hline Observations & 15,410 & 15,410 & 15,410 & 15,410 & 15,410 & 15,410 & 15,410 & 15,410 & 15,410 \\
\hline R-squared & 0.376 & 0.335 & 0.134 & 0.076 & 0.523 & 0.117 & 0.229 & 0.216 & 0.181 \\
\hline No. unique firms & 2,605 & 2,605 & 2,605 & 2,605 & 2,605 & 2,605 & 2,605 & 2,605 & 2,605 \\
\hline Clustered SE & Firm & Firm & Firm & Firm & Firm & Firm & Firm & Firm & Firm \\
\hline Year FE & included & included & included & included & included & included & included & included & included \\
\hline Firm FE & included & included & included & included & included & included & included & included & included \\
\hline Pval: TXPD_MNC=TXPD_DOM & 0.095 & 0.079 & 0.025 & 0.017 & 0.002 & 0.008 & 0.045 & 0.024 & 0.024 \\
\hline Pval: TXPD_MNC=CFBTRD_MNC & 0.057 & 0.297 & 0.700 & 0.000 & 0.165 & 0.006 & 0.068 & 0.096 & 0.003 \\
\hline Pval: TXPD_DOM=CFBTRD_DOM & 0.554 & 0.629 & 0.018 & 0.009 & 0.827 & 0.202 & 0.636 & 0.641 & 0.249 \\
\hline
\end{tabular}

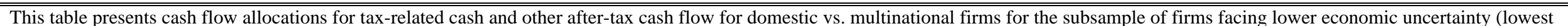

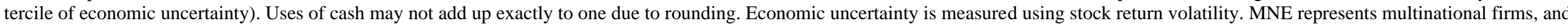

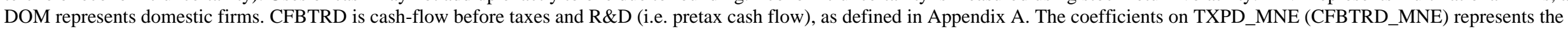

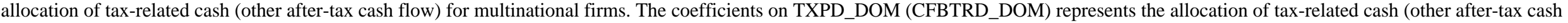

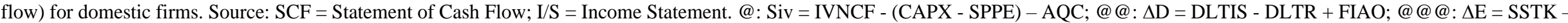

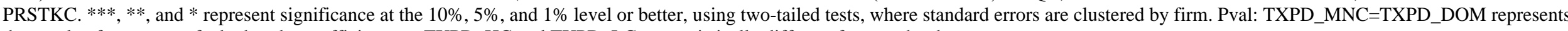
the p-value from a test of whether the coefficients on TXPD_HC and TXPD_LC are statistically different from each other, etc. 
TABLE 9: Allocation of Cash Flow for Domestic and Multinational Firms In Times of Higher Economic Uncertainty

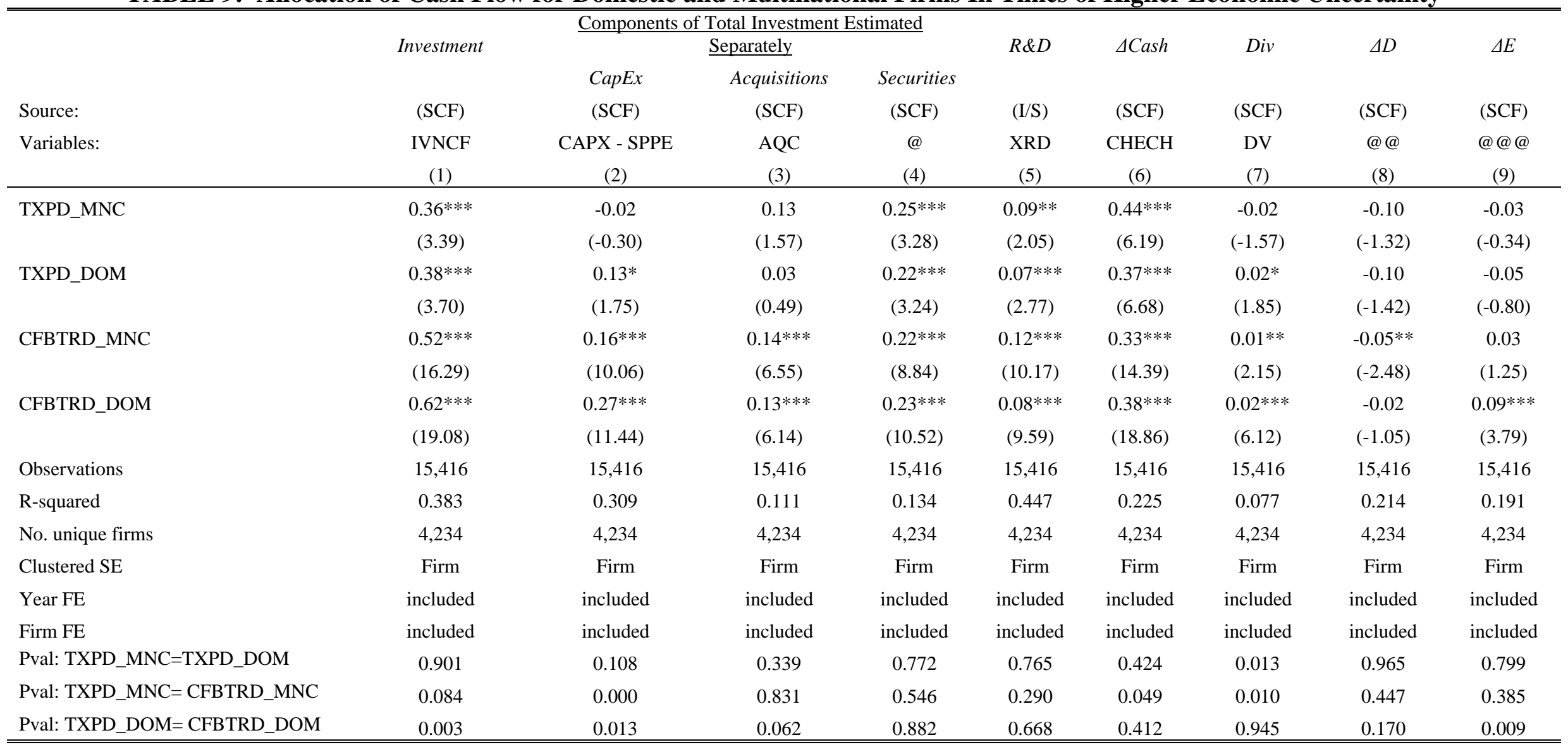

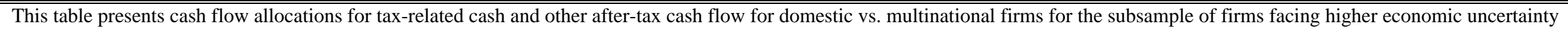

(highest tercile of economic uncertainty). Uses of cash may not add up exactly to one due to rounding. Economic uncertainty is measured using stock return volatility. MNE represents

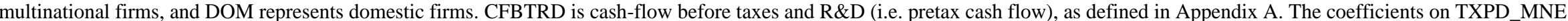

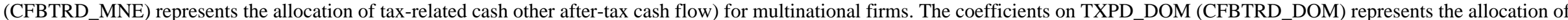

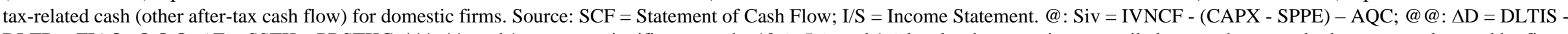

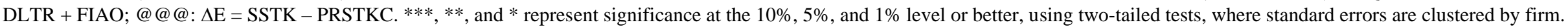

Pval: TXPD_MNC=TXPD_DOM represents the p-value from a test of whether the coefficients on TXPD_HC and TXPD_LC are statistically different from each other, etc. 
TABLE 10: The Allocation of Tax-Related Cash and Other After-Tax Cash Flow for Loss Firms

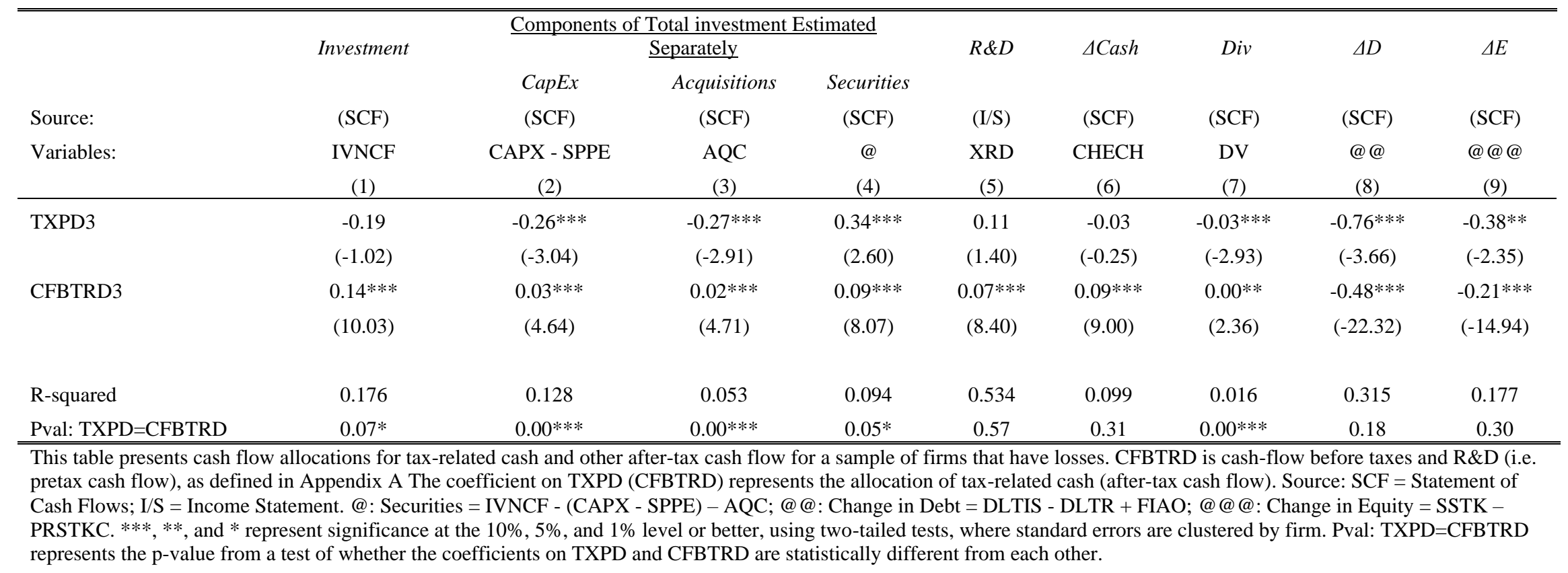

